\title{
Corrosion Behavior and Surface Treatment of Cladding Materials Used in High-Temperature Lead-Bismuth Eutectic Alloy: A Review
}

\author{
Hao Wang ${ }^{1}$, Jun Xiao ${ }^{1}$, Hui Wang ${ }^{1}$, Yong Chen ${ }^{1, *}$, Xing Yin ${ }^{1, *}$ and Ning Guo ${ }^{2, *}$ (I) \\ 1 Science and Technology on Reactor Fuel and Materials Laboratory, Nuclear Power Institute of China, \\ Chengdu 610041, China; wanghao_mse@163.com (H.W.); xiaojunmse@sohu.com (J.X.); \\ qinghe5525@163.com (H.W.) \\ 2 School of Materials and Energy, Southwest University, Chongqing 400715, China \\ * Correspondence: chenyong-67@163.com (Y.C.); yinxingwt@163.com (X.Y.); \\ guoning_1000@163.com or whc34@swu.edu.cn (N.G.)
}

check for updates

Citation: Wang, H.; Xiao, J.; Wang, H.; Chen, Y.; Yin, X.; Guo, N. Corrosion Behavior and Surface Treatment of Cladding Materials Used in High-Temperature Lead-Bismuth Eutectic Alloy: A Review. Coatings 2021, 11, 364. https://doi.org/10.3390/coatings 11030364

Academic Editor: Luigi Calabrese

Received: 28 February 2021

Accepted: 18 March 2021

Published: 23 March 2021

Publisher's Note: MDPI stays neutral with regard to jurisdictional claims in published maps and institutional affiliations.

Copyright: (c) 2021 by the authors. Licensee MDPI, Basel, Switzerland. This article is an open access article distributed under the terms and conditions of the Creative Commons Attribution (CC BY) license (https:/ / creativecommons.org/licenses/by/ $4.0 /)$.

\begin{abstract}
Liquid metal fast reactors were considered to be the most promising solution to meet the enormous energy demand in the future. However, corrosion phenomenon caused by the liquid metal, especially in high-temperature lead-bismuth coolant, has greatly hindered the commercialization of the advanced Generation-IV nuclear system. This review discussed current research on the corrosion resistance of structural materials (such as EP823, T91, ODS, and authentic steels) in high-temperature liquid metal served as reactor coolants. The current corrosion resistance evaluation has proved that even for the excellent performance of EP823, the structural material selected in pressurized water reactor is not the ideal material for operation in the high-temperature lead-bismuth eutectic (LBE). Furthermore, the latest coating technologies that are expected to be applied to cladding materials for coolant system were extensively discussed, including Al-containing coatings, ceramic coatings, oxide coatings, amorphous coatings and high-entropy alloy coatings. The detailed comparison summarized the corrosion morphology and corrosion products of various coatings in LBE. This review not only provided a systematic understanding of the corrosion phenomena, but also demonstrated that coating technology is an effective method to solve the corrosion issues of the advanced next-generation reactors.
\end{abstract}

Keywords: fast reactor; LBE; corrosion; cladding material; Al-containing coating

\section{Introduction}

Nuclear energy has been a crucial energy source for social development [1,2]. Since Fermi built the first reactor, nuclear reactors have provided electricity for humans for nearly eighty years. In addition, nuclear energy has been used to drive submarines, aircraft carriers, etc., and in the future may also provide sufficient energy for space stations [3]. However, some serious nuclear accidents in Fukushima, Three-Miles Island, and the Chernobyl have aroused great attention to nuclear safety [4], which greatly hindered the further application of nuclear energy.

In order to develop safer and more efficient nuclear energy, based on over 50 years of experiences on the operation of nuclear power plants, the Generation-IV International Forum (GIF) proposed six advanced nuclear systems in 2002, including very-hightemperature-reactor (VHTR), sodium-cooled fast reactor (SFR), supercritical water-cooled reactor (SWCR), gas fast reactor (GFR), molten salt reactor (MSR), and lead-cooled fast reactor (LFR) [5-8]. Among them, LFR makes full use of the excellent heat-carrying capacity of liquid metal and can operate under constant pressure for a long time. Lead-bismuth eutectic (LBE) is considered as heat transfer medium for the LFR system and the accelerator-driven system (ADS) due to its low melting point $\left(125^{\circ} \mathrm{C}\right)$ and high boiling point $\left(1670^{\circ} \mathrm{C}\right)$ [9-11]. 
Therefore, LBE is a promising coolant with high thermal conductivity that not only enhance power density but also provide a strategy to ensure reactor safety.

The corrosion behavior of structure materials in LBE mainly includes oxidation, dissolution and erosion process, which is different from other advanced reactors [12]. Both experimental and theoretical results have demonstrated that the current structural materials will be destroyed by corrosion in the LBE environment with high-temperature and high neutron flux [13-16]. Thus, the compatibility between the cladding materials and LBE is considered as the main limiting factor for the commercialization of the LFR systems [17-20]. Although a large number of corrosion experiments have been conducted on structural materials and the protective coatings, the feasibility of the cladding materials or coated materials used in the LBE-LFR is still unclear. In this review, we discussed the corrosion behavior of the cladding materials and their coatings in the LBE from the perspective of microstructure, temperature and flowing rate of the LBE. Additionally, the latest coating technologies that are expected to be applied to the cladding materials in LBE were also discussed.

\section{Candidate Cladding Materials for LBE-LFR}

Ferritic/martensitic (F/M) steel, austenitic steels, and oxide dispersion-strengthened (ODS) alloys are considered to be promising candidate materials for these advanced nuclear systems [21-25]. Due to its high thermal conductivities, lower expansion coefficients, F/M steels, such as T91, HT-9, 1.4718, EP823, HCM12A, etc., can be considered for the generation IV nuclear reactors [26-29]. Figure 1 shows corrosion morphology and element distributions of the typical F/M steels corroded in the high-temperature LBE. For the T91 steels (Figure 1a,b), after $8039 \mathrm{~h}$ corrosion in $450{ }^{\circ} \mathrm{C}$ LBE with flow rate $2 \mathrm{~m} / \mathrm{s}$ and $1.1 \times 10^{-6}$ wt.\%, duplex oxide layer (outer layer of iron oxide $\left(\mathrm{Fe}_{3} \mathrm{O}_{4}\right)$ and the inner layer of $\mathrm{Fe}-\mathrm{Cr}$ spinel $\left.\left([\mathrm{Fe}, \mathrm{Cr}]_{3} \mathrm{O}_{4}\right)\right)$ with a thickness of $9.83( \pm 0.65) \mu \mathrm{m}$ was clearly observed, and its thickness was considered to be not acceptable for long life-time reactor [30]. Such duplex oxide layer was also found in the HT-9 stainless steel after corrosion of $3000 \mathrm{~h}$ in $550{ }^{\circ} \mathrm{C}$ LBE with flow rate $2 \mathrm{~m} / \mathrm{s}$ and $10^{-6} \mathrm{wt} . \%$ oxygen concentration. The outer layer is also $\mathrm{Fe}_{3} \mathrm{O}_{4}$, but the inner layer was composed of spinel $[\mathrm{Fe}, \mathrm{Cr}]_{3} \mathrm{O}_{4}$ and high $\mathrm{Cr}$ enriched areas (see Figure 1c,d) [31]. This type of oxide layer was believed to be essential for protecting steels from LBE corrosion. Al and Si are considered to be alloying elements that improve the corrosion resistance of structural materials. Recently, it was reported that 9Cr-3Si (1.4718) steel alloyed with $\mathrm{Si}$ was very stable (12,546 h) in LBE with an oxygen concentration of $10^{-6}$ wt. $\%$ at $450^{\circ} \mathrm{C}$ [32], as shown in Figure 1e,f. This is because when exposed to LBE, oxides rich in $\mathrm{Cr}$ and $\mathrm{Si}$ are formed on the surface of the steels, which significantly improves the corrosion resistance. When exposed to LBE with a temperature of $470{ }^{\circ} \mathrm{C}$, a dissolved oxygen of $10^{-6} \mathrm{wt} . \%$, and a flow rate of $2 \mathrm{~m} / \mathrm{s}, 12 \mathrm{Cr}-2 \mathrm{Si}$ (EP-823) steel had a thinner oxide layer compared to T91 [33]. It was reported that $\mathrm{Si}$ was enriched in the dual phase oxide layer composed of spinel Fe and $\mathrm{Cr}$ mixed oxide. However, the EP823 did not show significantly better corrosion resistance than the steel without $\mathrm{Si}$ but higher $\mathrm{Cr}$ (e.g., 1.4970 steel containing $15 \mathrm{wt} . \% \mathrm{Cr}$ ), under similar conditions $\left(460^{\circ} \mathrm{C}\right.$, oxygen concentration of $10^{-6} \mathrm{wt} . \%$, flowing rate of $2 \mathrm{~m} / \mathrm{s}$ for $333 \mathrm{~h}$, as shown in Figure $1 \mathrm{~g}$. The third generation $12 \mathrm{Cr}$ ferritic steels with tempered martensitic HCM12A (12Cr-2W-0.4Mo$1 \mathrm{Cu}-\mathrm{V}, \mathrm{Nb}$ ) are also investigated for its possible application in high-temperature LBE [34]. From the cross-sectional image, typical duplex oxide structure was observed in Figure $1 \mathrm{~h}$ with an outer layer of $\mathrm{Fe}$ oxide $\left(\mathrm{Fe}_{3} \mathrm{O}_{4}\right.$, magnetite) about $6 \mu \mathrm{m}$ thickness, and each layer are ferrochrome spinel structure. The EDS results showed that LBE penetrated into the outer layer of $\mathrm{Fe}_{3} \mathrm{O}_{4}$, while no LBE element was detected in the spinel layer (Figure 1g). 

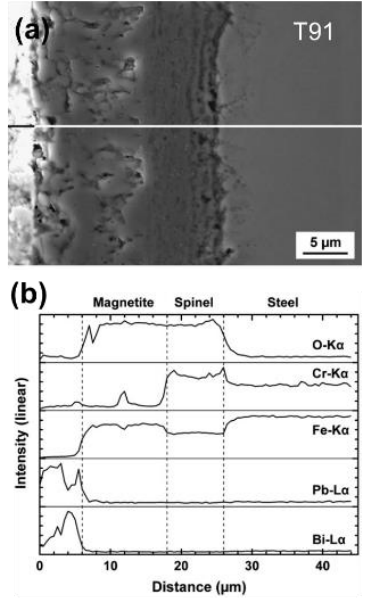

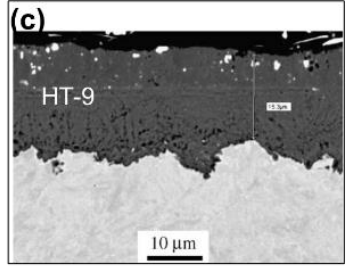

(d)

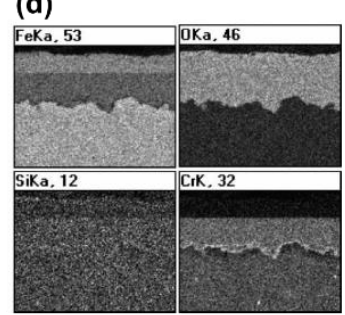

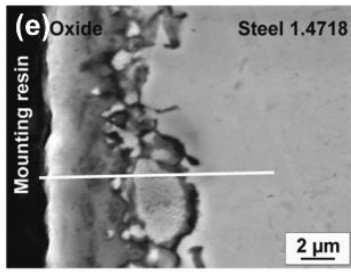

(f)

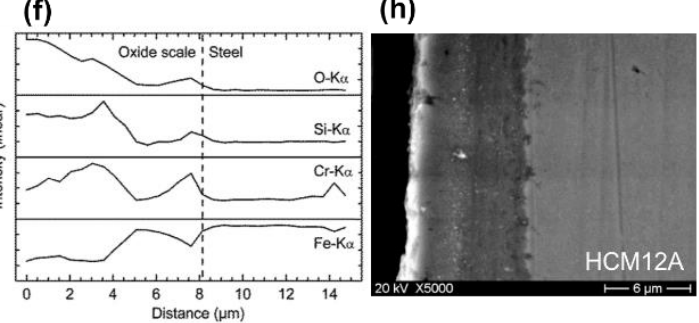

Figure 1. SEM corrosion morphology and EDS element distributions of ferritic/martensitic (F/M) steel after lead-bismuth (LBE) corrosion. (a,b) T91 [30], (c,d) HT-9 [31], (e,f) 1.4718 steel [32], (g) EP823 [33], (h) HCM12A [34]. Figure 1a,b reprinted with permission from Reference [30]. Copyright 2012 Elsevier. Figure 1c,d reprinted with permission from Reference [31]. Copyright 2008 Elsevier. Figure 1e,f reprinted with permission from Reference [32]. Copyright 2016 Elsevier. Copyright 2008 Elsevier. Figure 1g reprinted with permission from Reference [33]. Copyright 2001 Elsevier. Figure 1h reprinted with permission from Reference [34]. Copyright 2006 Elsevier.

The inner oxide layer with $\mathrm{Cr}$ enrichment is the final protective oxide layer. Oxidation is driven by the outward diffusion of Fe cations through the oxide layer from the diffusion zone of the bulk, while oxygen elements diffuse inward through the oxide layer into the diffusion zone. The iron oxide/spinel layer interface is continuously migrating inward. Based on this physical model and the known diffusion behavior of the elements, it is possible to predict the concentrations of $\mathrm{Fe}, \mathrm{Cr}$, and $\mathrm{O}$ in each layer. One would expect the oxygen content to be greatest in the oxide layer, falling to zero in volume after passing through the diffusion zone. Cr should be virtually absent in the outer layers, maximum in the spinel layer, and then return to the bulk alloy concentration. Finally, Fe should be prevalent in the outer layers, but suppressed in the spinel layer and diffusion zone before rising back to its alloy concentration (Figure 2).

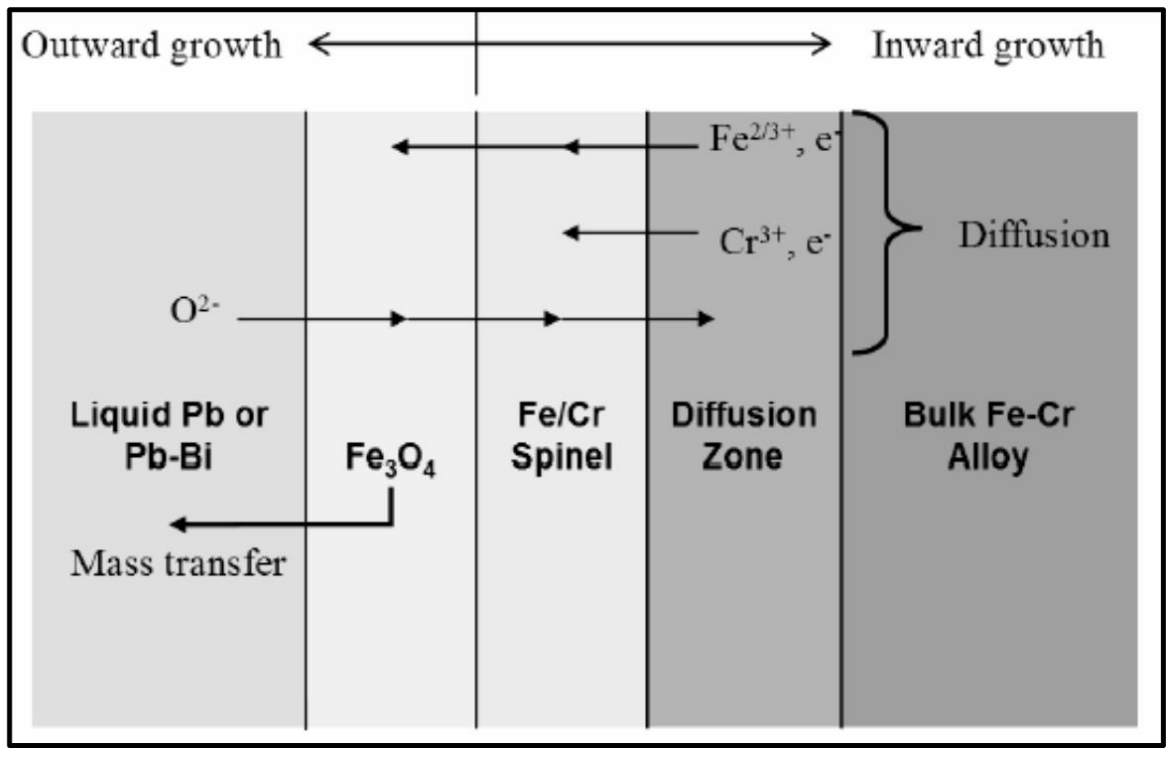

Figure 2. Corrosion mechanism of F/M steel in LBE [35]. 


\section{Surface Coatings of Cladding Materials for LBE-LFR}

Surface coating technology is one of the most common methods to improve the corrosion resistance of materials that can be directly used in the next generation nuclear system [36], such as pack-cementation [37-39], physical vapor deposition (PVD) [40-42], pulsed laser deposition/cladding [43-45], plasma electrolytic oxidation [46-48], cathodic arc ion plating $[49,50]$, etc. Compared with surface alloying, surface coating technology can introduce high-entropy alloys and ceramics with high heat resistance and corrosion resistance, and has the potential to greatly improve the corrosion resistance of steels. Surface coating technology needs to pay attention to two points: one is that the bonding force between the coating and the substrate should be strong enough to ensure that the coating will not easily fall off; the second is that the formation temperature of the coating should not be too high to avoid the structure coarsening and performance deterioration of the steel substrate.

\subsection{Al-Containing Coatings}

Alumina has high heat resistance, high density, and the formation Gibbs energy is very low, the introduction of an $\mathrm{Al}_{2} \mathrm{O}_{3}$ layer on the steel surface can significantly improve the corrosion resistance in LBE [51]. Generally, the alumina layer can be introduced via alloying [52] or surface alloying combined with subsequent pre-oxidation treatment or directly immersed in LBE containing oxygen. For steels, overall aluminum alloying may result in a decrease in material strength $[23,53]$, while surface aluminizing can improve surface corrosion resistance without affecting the strength of the base steel. The surface aluminizing can be achieved by thermal diffusion (e.g., pack cementation [54], hot-dip aluminizing [55]) or rapid surface heating/rapid cooling processes (e.g., laser [56], electron beam [57], and micro-arc oxidation [58], etc.). Kurata et al. [55] reported that $\mathrm{Pb}$ and Bi elements did not penetrate into the surface aluminized steels after $3000 \mathrm{~h}$ corrosion in LBE at $550{ }^{\circ} \mathrm{C}$, which was mainly due to the surface $\mathrm{Al}$ oxides and Al-containing intermetallic compounds served as barrier roles. Moreover, $\mathrm{Fe}_{4} \mathrm{Al}_{13}$ and $\mathrm{Fe}_{2} \mathrm{Al}_{5}$ identified before corrosion disappeared after the corrosion test, while the intermetallic compounds FeAl were observed before and after the corrosion test [59-62]. Such results indicated that the alloying layer containing FeAl had excellent corrosion resistance. Due to the high solubility of $\mathrm{Al}$ in LBE, the corrosion behavior was mainly controlled by the dissolution process if there was no oxygen source to form the protective layer of $\mathrm{Al}_{2} \mathrm{O}_{3}$.

In all application areas of coatings, such as cutting tools, thermal barrier coatings, and lubricant coatings, interface bonding with high enough strength is potentially the basis of realizing its various functions. Many studies have been trying to improve the stability of bonding strength at the interface of two different materials, including surface structure, texture and process optimization. However, it is difficult to control the interface bonding strength for a wide range of commercial applications. The latest reported pulsed electron beam technology (GESA-Gepulste Elektronen Strahl Anlage) may solve this issue. The kinetic energy of electrons is in the range of 50 to $150 \mathrm{keV}$, and the energy density is 20 to $50 \mathrm{~J} / \mathrm{cm}^{2}$ on the material surface. The microsecond pulse duration is long enough to melt the surface layer up to $50 \mu \mathrm{m}$, and the cooling rate is abnormally fast due to the high thermal conductivity of substrate [63]. This technology is considered to be one of the most effective methods to improve the interface bonding strength and corrosion resistance of the cladding materials. Al foil with the thickness of $18 \mu \mathrm{m}$ was placed on the steels and followed by GESA treatment to prepare Al-containing coatings, as shown in Figure 3a,b [64]. Furthermore, the quality of alloying layer can be improved by Al coatings fabricated by magnetron sputtering [65]. Figure 3c-e present the cross section of ODS, T91, and E911 steel after $2000 \mathrm{~h}$ of LBE corrosion at $550{ }^{\circ} \mathrm{C}$ with oxygen concentration of $10^{-6} \mathrm{wt} . \%$. Before the corrosion test, all steel specimen is all only treated with GESA to modify surface properties. However, the effect of GESA greatly boost oxide rate comparing with no GESA treatment. The thickness of oxide layer $\left(550{ }^{\circ} \mathrm{C}, 2000 \mathrm{~h}, 1 \times 10^{-6} \mathrm{wt} . \%\right.$, flowing LBE) is $14-15 \mu \mathrm{m}$ for ODS, 19-20 $\mu \mathrm{m}$ for E911, and 8-22 $\mu \mathrm{m}$ for T91, respectively. 
This acceleration in oxide process is mainly due to that the smaller grain size induced by GESA, and large amounts of grain boundaries provides channel for the transporting of cations, including $\mathrm{Fe}+, \mathrm{Cr}+, \mathrm{Ni}+, \mathrm{O}-$. The oxide layer of EP911 shows typically duplex layer structure that consist of porous magnetite layer $\left(\mathrm{Fe}_{3} \mathrm{O}_{4}\right)$ and $\mathrm{Fe}-\mathrm{Cr}-\mathrm{O}$ spinel with cracks extended to substrate (Figure 3i). The oxide layer of ODS shows a different structure that is dense without crack (Figure 3c). But, corrosion test in flowing lead at $550{ }^{\circ} \mathrm{C}$, oxide layer of ferritic-martensitic Optifer IVc and EM10 shows no difference when applied GESA treatment [66]. It is possible that oxide growing and oxide structure are largely determined by the alloying element of structural steel and exposure environment. Figure $3 g$ shows cross-sectional image of ODS that treated by Al containing alloying of GESA technology after exposure to flowing LBE of $2000 \mathrm{~h}$, and protective oxide layer $\mathrm{Al}_{2} \mathrm{O}_{3}$ was formed on its surface.
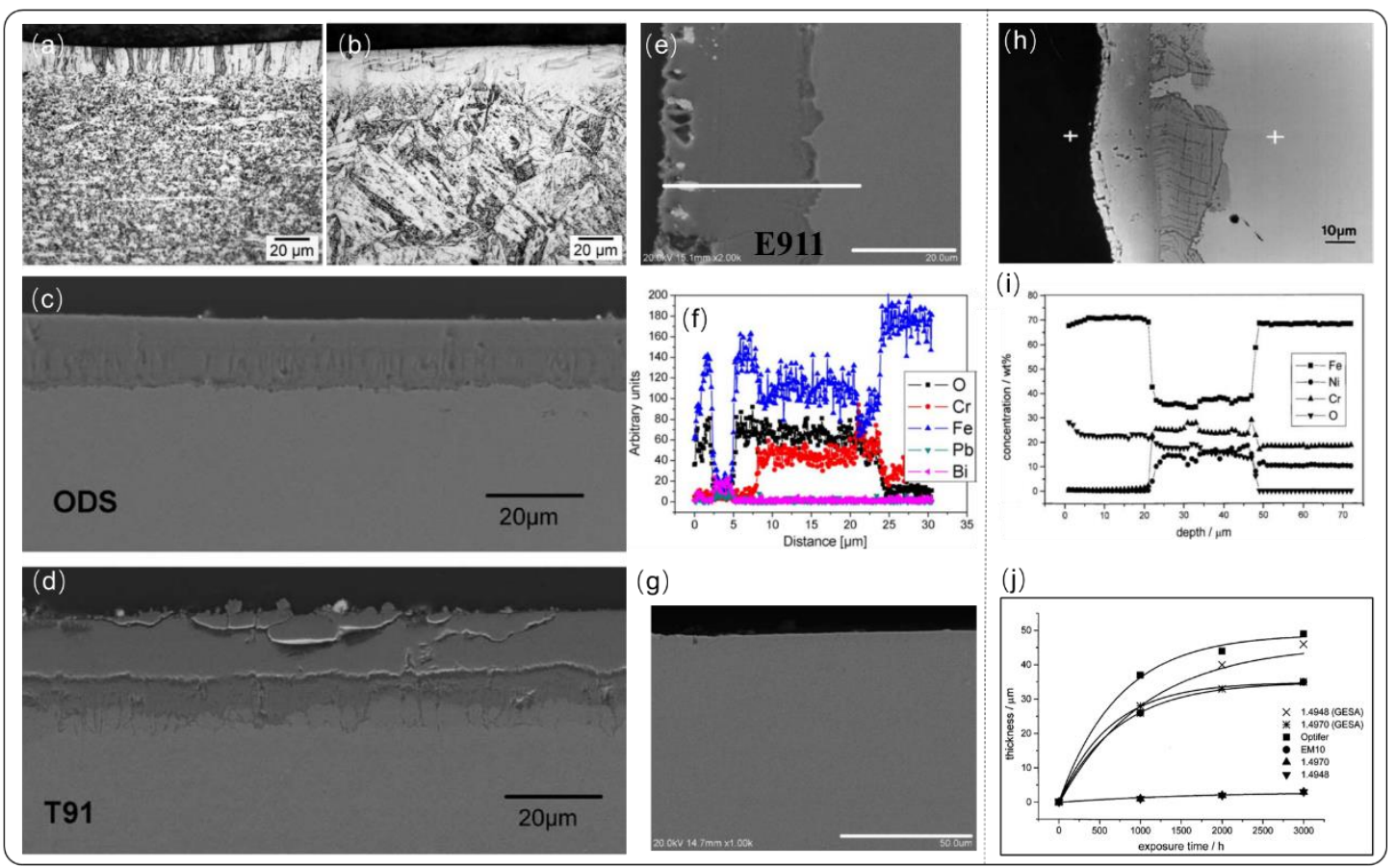

Figure 3. Gepulste Elektronen Strahl Anlage (GESA) treated coatings and corrosion performance. (a,b) Cross-sectional images of Al-coating on oxide dispersion-strengthened (ODS) and E911. (c-e) Cross-section images of the Al-coated ODS, T91 and E911 after corrosion test. (f) Element distribution of E911after GESA treatment. (g) Cross section of ODS with Al alloying. (h) Cross section of 1.4948 steel after GESA treatment. (i) Element distribution from EDX energy spectrum of EP911. (j) Summary of oxide layer thickness at $550{ }^{\circ} \mathrm{C}$ in flowing lead $[65,66]$. Figure 3a-g is reprinted with permission from Reference [65]. Copyright 2006 Elsevier. Figure 3h-j is reprinted with permission from Reference [66]. Copyright 2001 Elsevier.

The function of oxide layer is to prevent alloy element from the bulk to the LBE and vice versa. On the other hand, how to evaluate the thickness of oxide layer is important for long time operating in reactor that not only change heat transfer efficiency of cladding, but also influence mechanical properties of structural materials.

In order to investigate corrosion resistance of Al-coating on the surface of T91, a thickness of 5-20 $\mu \mathrm{m}$ Al-coating were treated by GESA with accelerate voltage of $120 \mathrm{kV}$ and energy density $20-50 \mathrm{~J} / \mathrm{cm}^{2}$ on the specimen (Figure 4a) [57]. As shown in Figure $4 \mathrm{~b}$, the $\mathrm{Al}$ content decreased with increasing number of electron beam pulse, because of the evaporation surface atoms induced by high energy electron beam and the migration of $\mathrm{Al}$ atoms toward inner parts [57]. Figure $4 \mathrm{c}$ shows the feasibility of microsecondpulsed intense electron beams (MIEB) technology used to protect fuel cladding tubes made of 1.4970 steel [57]. Figure $4 \mathrm{~d}$ is a case of surface coating with Fe78Cr14A18 [57]. 
After exposure to LBE for $5000 \mathrm{~h}$ at $600{ }^{\circ} \mathrm{C}$, the tube also shows shiny surface without any corrosion phenomenon. Figure $4 \mathrm{e}$ is a case of T91 and 1.4970 tubes with $\mathrm{FeCrAl}$ coatings treated by MIEB [57]. After corrosion test $\left(16547 \mathrm{~h}\right.$ at $550{ }^{\circ} \mathrm{C}$ and a high oxygen concentration of $1-4 \times 10^{-6} \mathrm{wt} . \%$ ), the coating has severe corrosion due to the low $\mathrm{Al}$ content (less than $3 \mathrm{wt} . \%$ ). Such observation directly proved that $\mathrm{FeCrAl}$ coatings with appropriate $\mathrm{Al}$ content between $3-10 \mathrm{wt} . \%$ shows excellent corrosion resistance for long time. Previous researches have verified that corrosion resistance is highly depend on the $\mathrm{Al}$ content of surface coatings, high $\mathrm{Al}$ content specimen have demonstrated that $\mathrm{Al}$ element will dissolute in to liquid metal coolant. In opposite case, oxide layer can not be formed with low $\mathrm{Al}$ content [67]. With high energy bombardment of electron beam, the atoms at interface are mixed thoroughly, and the interface boundary disappeared that are beneficial for the adhesion of the coatings. Besides, it can be concluded that $\mathrm{Al}_{2} \mathrm{O}_{3}$ are grown on the surface less than $1 \mu \mathrm{m}$ from the EDX results (Figure $4 \mathrm{~g}$ ). Thus, it is the Al oxides protect the steel from the corrosion of high-temperature LBE. In this work, it should be noted that uniformity in coatings is a key factor to determine the corrosion resistance of alloying layer, especially it is difficult to apply on the tube specimen.

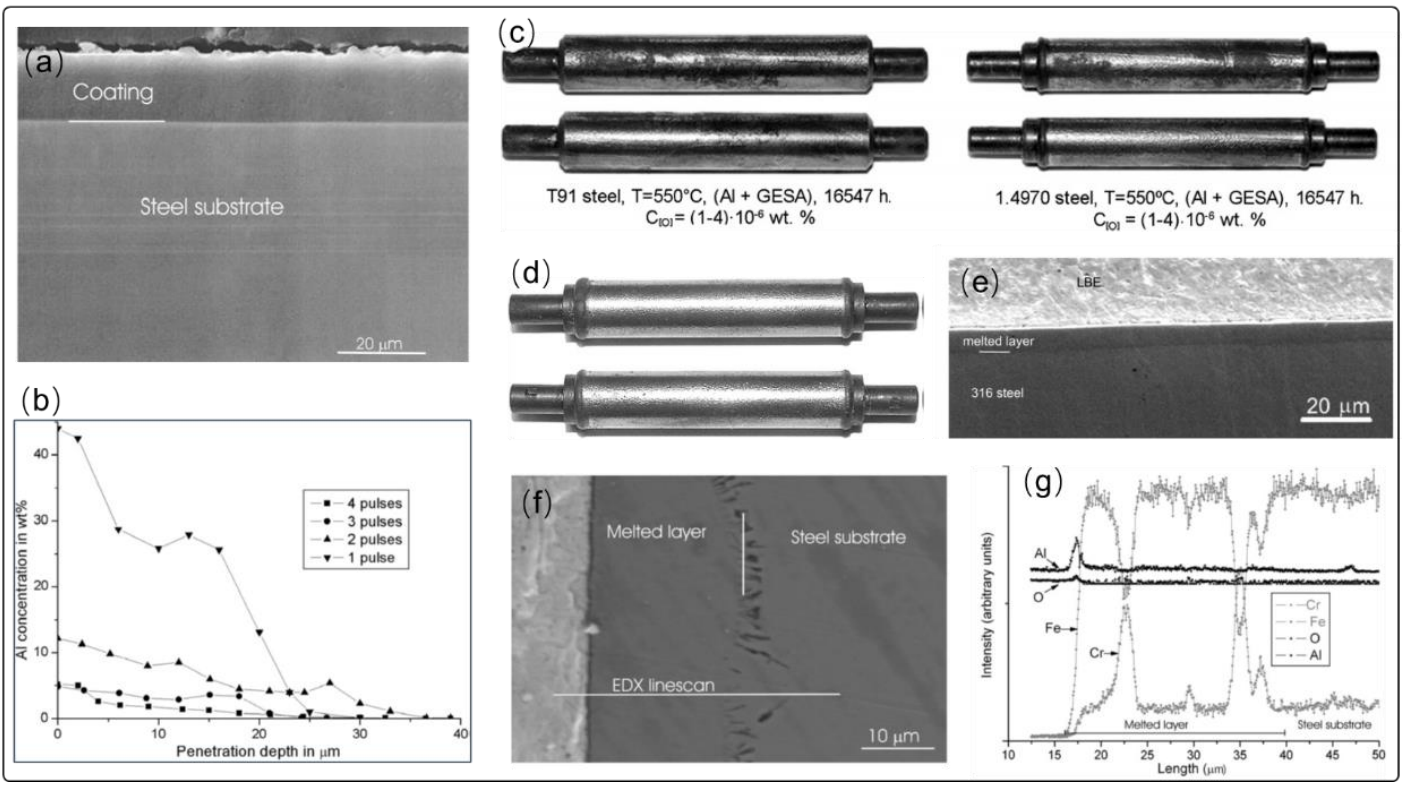

Figure 4. Al-containing coating prepared via GESA (a) and melting depth dependence of Al content under different number of pulse with energy density of electron beam $45 \mathrm{~J} / \mathrm{cm}^{2}$ (b), (c) Al-containing coating prepared via GESA process after corrosion test, (d) Fe78Cr14Al8 coating prepared by GESA, (e) corrosion morphology of Al-containing coatings treated by GESA exposure to LBE, (f) corrosion morphology of Al-containing coating after LBE corrosion and corresponding EDS element distribution (g) [57]. Figure 4 is reprinted with permission from Reference [57]. Copyright 2011 Elsevier.

Weisenburger et al. [39] used low pressure plasma spray (LPPS) to prepare FeCrAlY coating on T91 steel tubes. Figure 5a shows the corrosion morphology of the coated sample after corrosion in LBE at $550{ }^{\circ} \mathrm{C}$ with flowing rate of $1-1.2 \mathrm{~m} / \mathrm{s}$ and $10^{-6} \mathrm{wt} . \%$ oxygen. Although there are some dark parts on the surface that is similar with $\mathrm{Al}$ foil, the entire surface still shows shiny oxide layer after $2000 \mathrm{~h}$ compared with no coatings on specimen, indicating that protective layer is formed on the tubes. Figure $5 b, c$ present the corrosion morphologies of T91 steel without surface modification, and the oxide layer is $18-25 \mu \mathrm{m}$ in thickness at $480^{\circ} \mathrm{C}$ and $25-45 \mu \mathrm{m}$ at $550^{\circ} \mathrm{C}$. Figure $5 \mathrm{~d}$ presents the corrosion morphology after corrosion in LBE for $2000 \mathrm{~h}$ at $600{ }^{\circ} \mathrm{C}$. The FeCrAlY coatings shows very dense structure with a thin oxide layer, which is verified to be $\mathrm{Al}$ oxide layer $(<1 \mu \mathrm{m})$ via EDX scanning. From the image of optical microscopy, the melting depth of GESA reach up to $30 \mu \mathrm{m}$, and $\mathrm{Al}$ is also found at the interface of melting region and steel substrate. However, 
the $\mathrm{Al}$ content lower than $4 \mathrm{wt} . \%$ at the dark region is not enough to from protective $\mathrm{Al}$ oxide layer at oxygen concentration of $10^{-6} \mathrm{wt} . \%$.

Fetzer et al. [68] also investigated the corrosion resistance of FeCrAl and FeCrAlY coatings prepared by LPPS, especially the effect of element $\mathrm{Y}$ and Al content on the corrosive resistance of the coatings in a high-temperature $\mathrm{Pb}$ environment. They reported that the critical aluminum content is $8 \mathrm{wt} . \%$ for the formation of protective layer under the corrosion condition of $400-500{ }^{\circ} \mathrm{C}$ and an oxygen concentration of $10^{-6} \mathrm{wt} . \%$, and as the temperature increases, the critical $\mathrm{Al}$ content will decrease. They also pointed out that a small amount of yttrium $(<0.5 \mathrm{wt} . \%)$ in the coating facilitates the formation of the oxide layer, which can also improve the corrosion resistance. Thus, it was recommended to use the FeCrAlY coating instead of $\mathrm{FeCrAl}$ alloy to improve the high-temperature oxidation resistance of the bare steel.

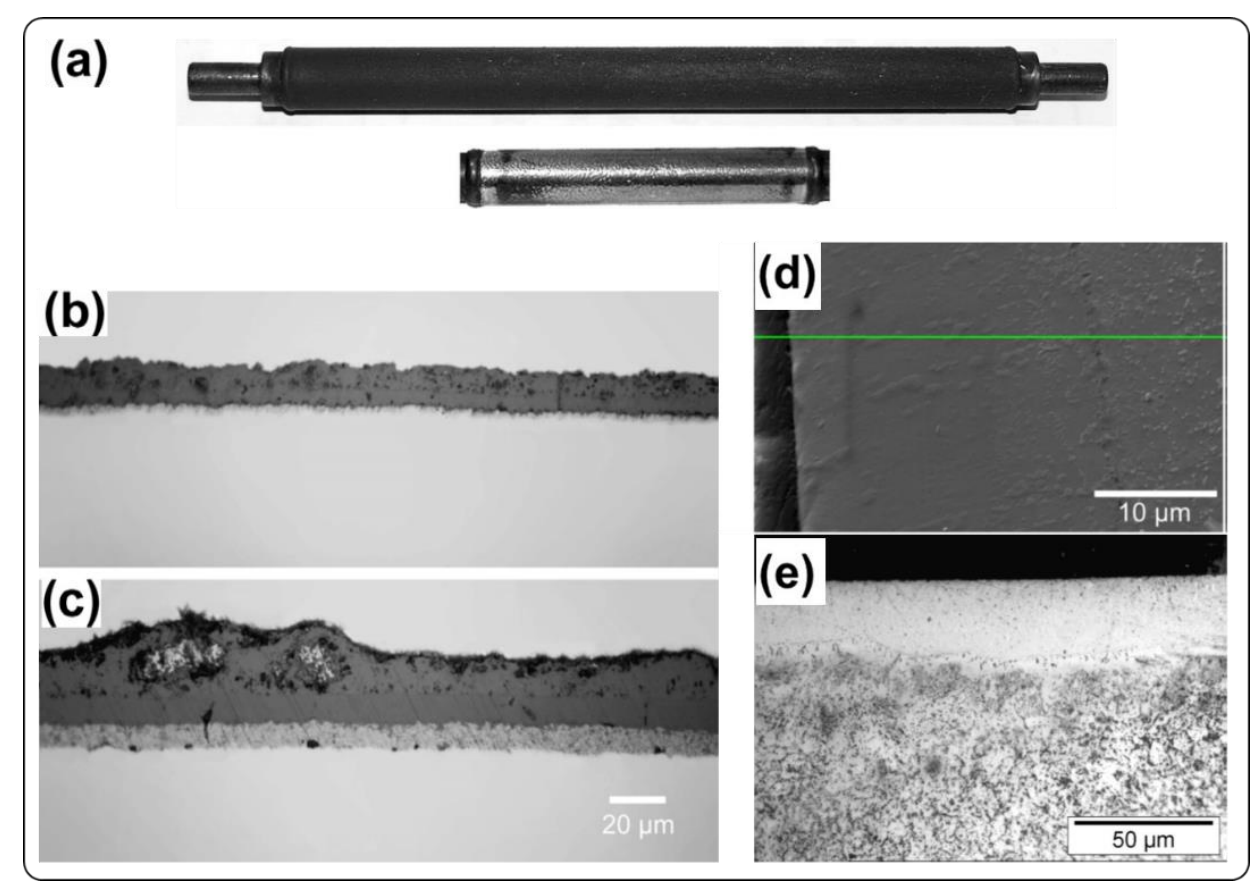

Figure 5. Physical photo of T91 cladding tubes without (dark) and with (shiny) FeCrAl coatings after corrosion test in LBE at $550{ }^{\circ} \mathrm{C}$ (a). T91 without coating after corrosion in LBE at $480{ }^{\circ} \mathrm{C}(\mathbf{b})$ and $550{ }^{\circ} \mathrm{C}$ (c). SEM photograph of T91 without FeCrAl coating after corrosion in LBE (d,e) [69]. Figure 5 is reprinted with permission from Reference [69]. Copyright 2008 Elsevier.

For high-temperature LBE coolants, the influence of shear stress on the protective coating should be considered to evaluate corrosion behavior. The influence of LBE flowing rate on cladding tubes at $550^{\circ} \mathrm{C}$ is shown in Figure 6. From the comparison of the uncoated and coated tubes under different flow rates of about 1,2 , and $3 \mathrm{~m} / \mathrm{s}$, the uncoated tubes present typical oxide layer. However, oxide layer maintains its magnetite structure only under $1 \mathrm{~m} / \mathrm{s}$, and this magnetite were eroded with thicker thickness under $2 \mathrm{~m} / \mathrm{s}$. At $3 \mathrm{~m} / \mathrm{s}$ of LBE, the magnetite structure completely disappeared after $2000 \mathrm{~h}$. The coated tube again showed no obvious corrosion phenomenon (Figure $6 \mathrm{~d}-\mathrm{f}$ ). To our best knowledge, many erosion models have been proposed for the flowing LBE, especially for evaluating the shear stress that imposed on the substrate, which can be expressed from the equation of Arrhenius as follows [70]:

$$
\begin{gathered}
\eta(T)=\eta \exp \left(\frac{E}{R T}\right) \\
\tau=\eta \frac{v}{h}
\end{gathered}
$$


where the $\tau$ is the shear stress (MPa), $T$ is the temperature of $\mathrm{LBE}(\mathrm{K}), R$ is the gas constant $8.314 \mathrm{~J} /(\mathrm{mol} \cdot \mathrm{K}), v$ is flowing rate of $\mathrm{LBE}(\mathrm{m} / \mathrm{s})$. As reported in the reference [71], the $\mathrm{Al}_{2} \mathrm{O}_{3}-\mathrm{TiO}_{2}$ multiphase ceramic coatings was prepared by flame spraying and laser in-situ reaction technology with a thickness of $80 \sim 100 \mu \mathrm{m}$. The measured interface bonding strength of coatings exceeds $1500 \mathrm{MPa}$, and shear stress about $280 \mathrm{MPa}$ which is far more than that induced by flowing LBE $47.35 \mathrm{MPa}$, which is calculated by above equations. Thus, the coating cannot be spalled by the flowing LBE. However, the oxide layer grown on the bare steel is lower than $10 \mathrm{MPa}$, which could be eroded by flowing LBE, especially for high shear stress $84.68 \mathrm{MPa}$ in $3 \mathrm{~m} / \mathrm{s}$ high flowing rate LBE.

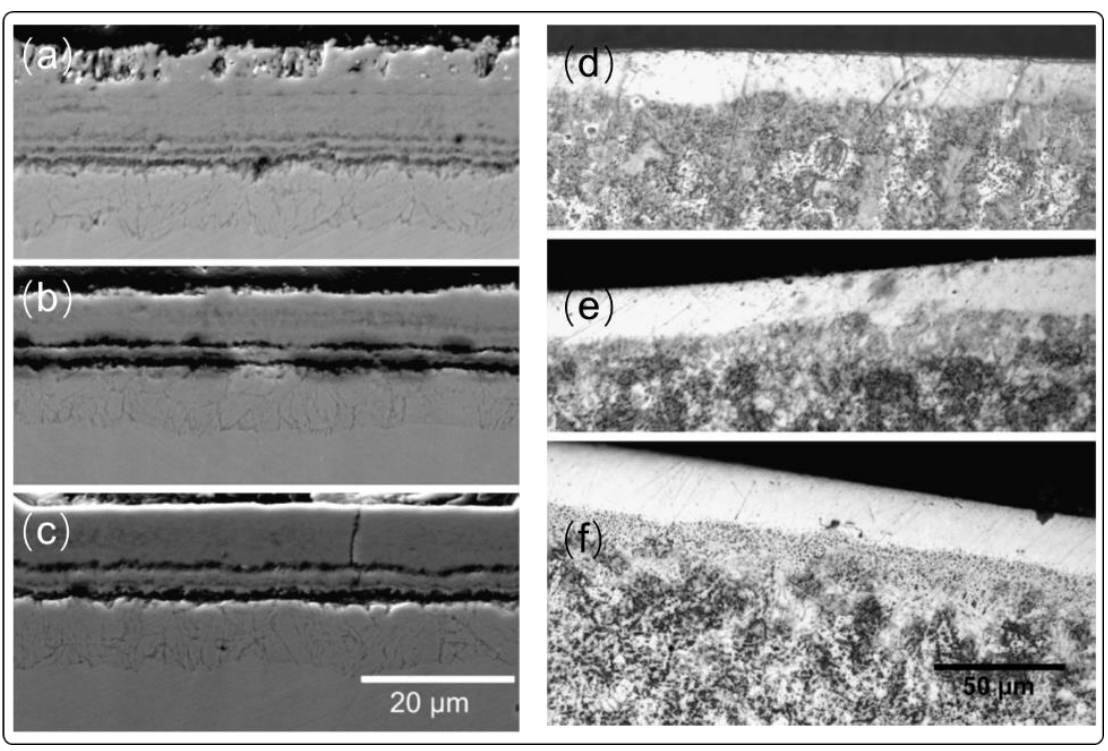

Figure 6. Influence of LBE flowing rate on the corrosion process. (a-c) corrosion morphologies of bare T91 after corrosion with flowing rate of $1 \mathrm{~m} / \mathrm{s}, 2 \mathrm{~m} / \mathrm{s}$, and $3 \mathrm{~m} / \mathrm{s}$, respectively. $(\mathbf{d}-\mathbf{f})$ corrosion morphologies of surface modified T91 after corrosion with flowing rate of $1 \mathrm{~m} / \mathrm{s}, 2 \mathrm{~m} / \mathrm{s}$, and $3 \mathrm{~m} / \mathrm{s}$, respectively [69]. Figure 6 is reprinted with permission from Reference [69]. Copyright 2008 Elsevier.

In addition to $\mathrm{Al}$, other strong and dense oxidation forming elements, such as $\mathrm{Si}$ [72] and $\mathrm{Ti}$ [73], have been introduced as coatings on the steel surface to improve the corrosion resistance in high-temperature LBE. Rivai and Takahashi [74] pointed out that tungsten (W) and molybdenum (Mo) exhibit high corrosion resistance to LBE at $700{ }^{\circ} \mathrm{C}$ for $1000 \mathrm{~h}$ (Figure $7 \mathrm{a}, \mathrm{b})$, while niobium $(\mathrm{Nb})$ is not compatible with the LBE at $700{ }^{\circ} \mathrm{C}$ (Figure $7 \mathrm{c}$ ). Mo and its alloys are susceptible to the formation of volatile $\mathrm{MoO}_{3}$ in oxidizing environments at temperatures $>600{ }^{\circ} \mathrm{C}$ [75], which weakens the corrosion resistance cladding. Mo reacts with dissolved oxygen and $\mathrm{Pb}$ in liquid $\mathrm{LBE}$ to produce a multilayer film. Recently, Cairang et al. [76] reported that $\mathrm{Mo}$ can react with dissolved oxygen and $\mathrm{Pb}$ in liquid $\mathrm{LBE}$ $\left(600{ }^{\circ} \mathrm{C}\right.$, oxygen-saturated) to produce a multilayer film consisting of $\mathrm{MoO}_{2}, \mathrm{PbMoO}_{4}$ and $\mathrm{Pb}_{2} \mathrm{MoO}_{5}$ from inner to outside (Figure 8). Therefore, it is necessary to control the oxygen concentration in the LBE for Mo or Mo alloy. Up to now, it has been noticed that W, Mo and other high melting point metals have acceptable corrosion resistance in high-temperature LBE. According to our literature survey results, the current research is still at the initial stage of the corrosion behavior of such metals themselves in LBE. The corrosion behavior of the typical cladding materials coated with high melting point metals in high temperature LBE is rarely reported. 


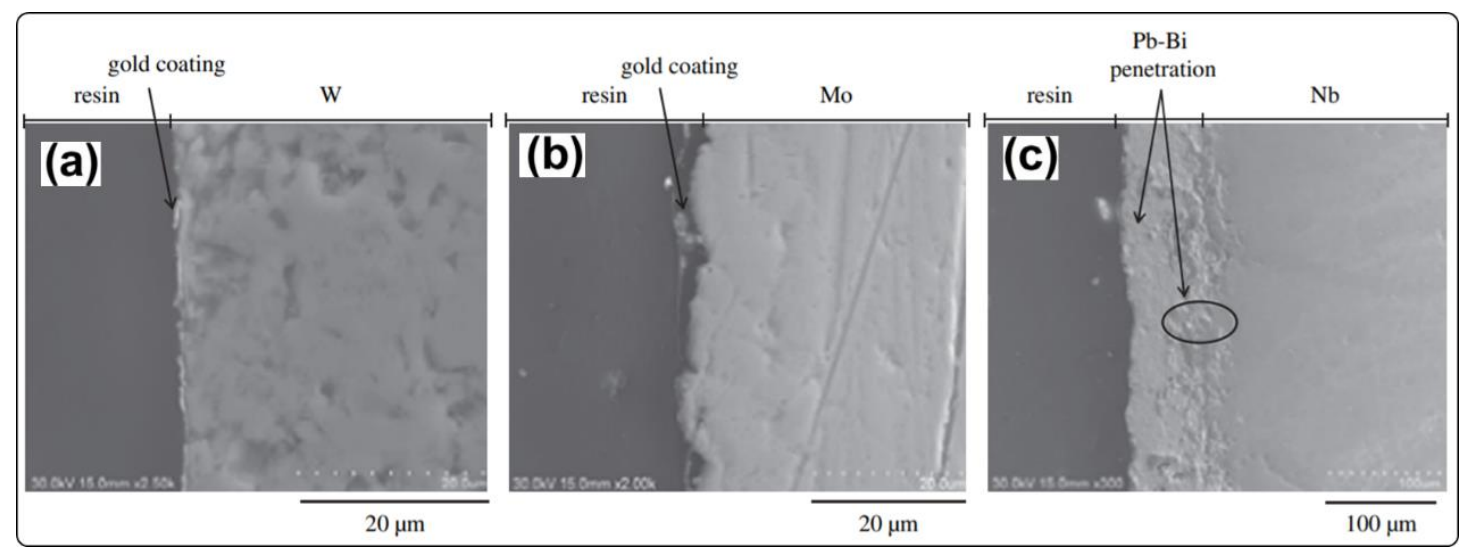

Figure 7. Cross-sectional morphology of refractory metals tungsten (a), molybdenum (b) and niobium (c) after $1000 \mathrm{~h}$ of corrosion in LBE at $700{ }^{\circ} \mathrm{C}$ [74]. Figure 7 is reproduced with permission from Reference [74]. Copyright 2008 Elsevier.
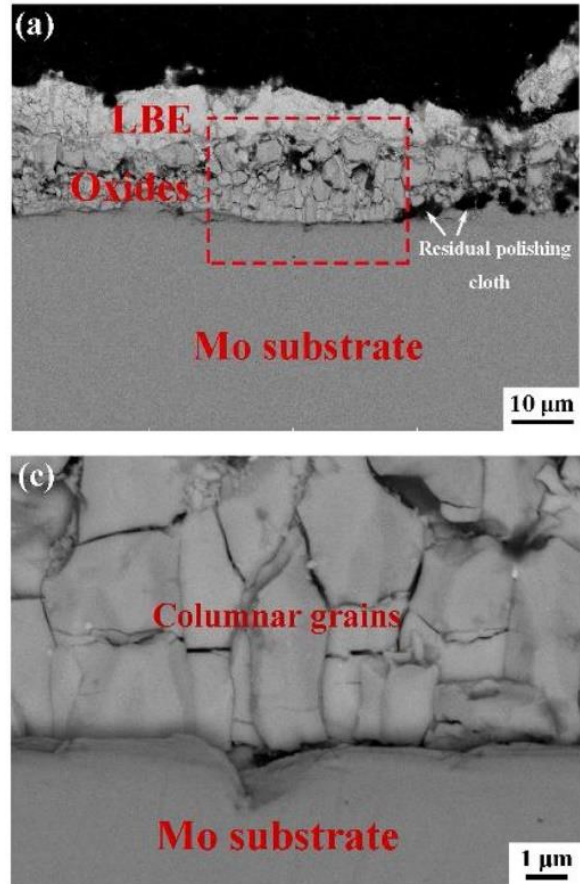

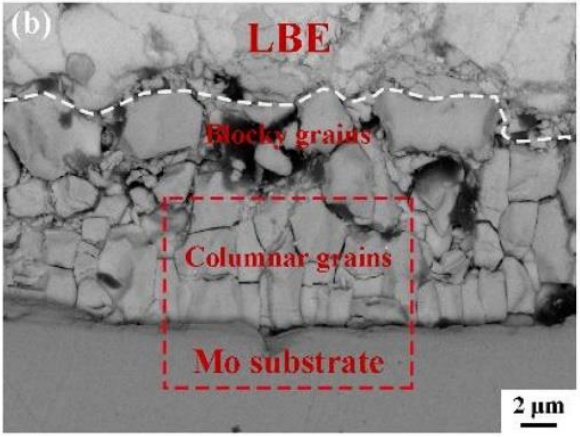

Liquid LBE

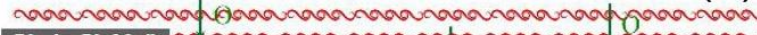

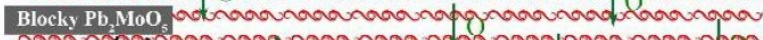

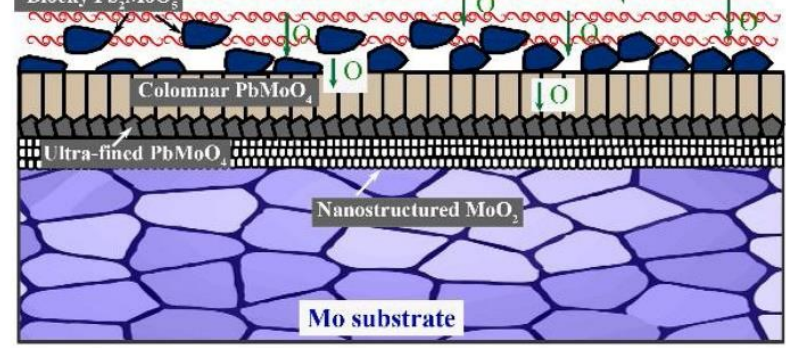

Figure 8. SEM images showing microstructure of Mo corroded in LBE at $600{ }^{\circ} \mathrm{C}$ for $20 \mathrm{~h}(\mathbf{a}-\mathbf{c})$, and schematic illustration multilayered oxide layers of Mo after LBE corrosion (d) [76]. Figure 8 is reproduced with permission from Reference [76]. Copyright 2021 Elsevier.

\subsection{Ceramic Coatings}

Ceramic has high strength and good high-temperature stability. It is an ideal coating to protect steel from corrosion in various harsh environments. $\mathrm{SiC}$ and $\mathrm{Ti}_{3} \mathrm{SiC}_{2}$ exhibit high corrosion resistance to LBE at $700{ }^{\circ} \mathrm{C}$ for $1000 \mathrm{~h}$, which means that they can be potential materials for high temperature LBE-cooled fast reactors [74]. TiAlN in which part of Ti atoms in face-centered-cubic ( $\mathrm{fcc}$ ) TiN replaced by $\mathrm{Al}$ atoms has good performance and been widely applied in cutting tool industry. The hardness and oxidation resistance of the coating can be modulated by atomic ratio of $\mathrm{Ti}$ and $\mathrm{Al}$. With this method, the hightemperature oxidation resistance of the coating has been increased to $800{ }^{\circ} \mathrm{C}$, which is only lower than that of $\mathrm{Al}_{2} \mathrm{O}_{3}$ ceramic coating [77-80]. Therefore, much efforts have been devoted to investigate compatibility of TiAlN coatings on structure materials.

TiAlN coatings for the increased operating temperature of next generation nuclear system are fabricated by high-power impulse magnetron sputtering (HiPIMS), which is 
newly developed coating technology with merits of high ion flux, high plasma density and stable deposition process $[81,82]$. F/M steel T91 was selected as the substrate that was heated to $400{ }^{\circ} \mathrm{C}$ during the deposition. The thickness of TiAlN is about $2.2 \mu \mathrm{m}$. The subsequent corrosion test $\left(550{ }^{\circ} \mathrm{C}, 1200 \mathrm{~h}, 10^{-6} \mathrm{wt} . \%\right.$, stagnant $\left.\mathrm{Pb}\right)$ is then performed on the TiAlN coatings. The surface morphology of bare steel T91 and TiAlN coatings before and after corrosion test is shown in Figure 9. Surface morphology of the uncoated T91exihibits scaly structure that extents to the inside of the steel. However, the coated T91 exhibits no damage phenomenon compared with the coatings before corrosion test. SEM and EDS result show that surface is rich in oxygen with acicular flakes structure (Figure 9d). This study indicates that it is possible to protect structure steel from the corrosion of liquid $\mathrm{Pb}$ via TiAlN coatings. However, the long-time performance of TiAlN need to be evaluated in the future.

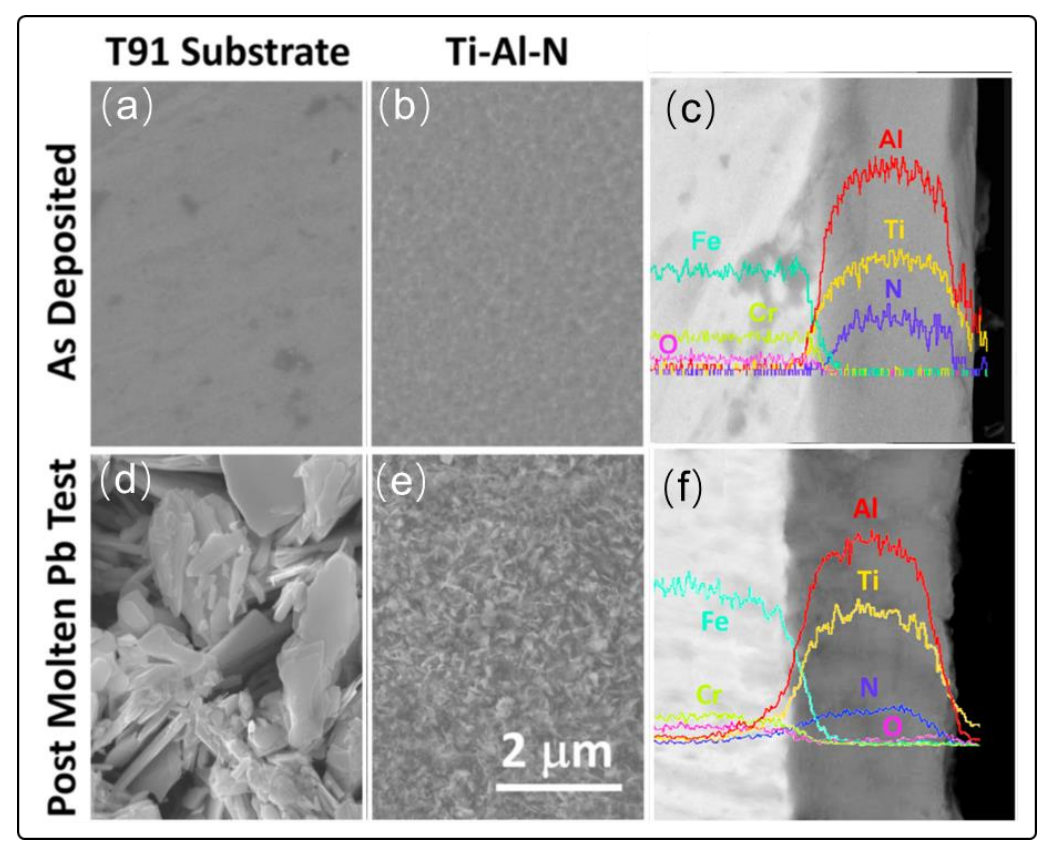

Figure 9. Corrosion performance of TiAlN coating in liquid $\mathrm{Pb}$ (a) SEM photo of T91 pre-corrosion surface (d) SEM photo of T91 post-corrosion surface $(\mathbf{b}, \mathbf{e})$ SEM photo of TiAlN coating before corrosion and corrosion dipstick (c,f) Cross-sectional elemental distribution curve of TiAlN coating before and after corrosion [81]. Figure 9 is reproduced with permission from Reference [81]. Copyright 2019 Elsevier.

$\mathrm{Cr} /$ TiAlN coatings on 316L, with thicknesses of $0.5 \mu \mathrm{m}$ and $4.35 \mu \mathrm{m}$, were fabricated by cathodic arc ion plating [83]. Figure 10a shows the cross-sectional morphology of the TiAlN after corrosion $\left(550^{\circ} \mathrm{C}, 500 \mathrm{~h}, 7 \times 10^{-3} \mathrm{wt} . \%\right.$, stagnant LBE). The coatings maintain its dense structure without any corrosion phenomenon. Furthermore, there are no defects or oxide layer detected on the surface. Figure 10b presents the cross-sectional morphology of the TiAlN $\left(600^{\circ} \mathrm{C}, 500 \mathrm{~h}, 2 \times 10^{-3} \mathrm{wt} . \%\right.$, stagnant LBE) after corrosion test. By increasing the temperature to $600{ }^{\circ} \mathrm{C}$, a thin oxide layer with a thickness of $500 \mathrm{~nm}$ was observed from high resolution SEM image in Figure 10c. This oxide layer main consists of $\mathrm{Ti}, \mathrm{Al}, \mathrm{O}$, and $\gamma-\mathrm{Al}_{2} \mathrm{O}_{3}, \mathrm{TiO}_{2}$ phase were further verified via $\mathrm{XRD}$ analysis. At higher temperature, the TiAlN coating also exhibits dense structure without any defects, and $\mathrm{Pb}$ and Bi elements are not detected inside the coating. Most importantly, wettability research between coatings and LBE provide a new way to understand interface behavior. Figure 10e is the case of the wettability of the TiAlN contacting with $\mathrm{LBE}$ at $300^{\circ} \mathrm{C}$ to $425^{\circ} \mathrm{C}$. The contact angle of coating before the corrosion test is $130^{\circ}$, and then it increased to $136^{\circ}\left(550^{\circ} \mathrm{C}\right)$ and $144^{\circ}$ $\left(600{ }^{\circ} \mathrm{C}\right)$ after corrosion test. Both temperature corrosion test showed poor wettability of the TiAlN with LBE, which is beneficial for improving the corrosion resistance of the 
coating. This study indicates that temperature is a key factor during variation of surface morphology when contacting LBE. However, a recent paper of observation shows complete opposite trend in temperature dependence of contact angle [84]. In fact, it is still unclear how oxide layer or surface condition affect the wettability of the coatings. Whatever, it is desirable to achieve poor wettability at the interface between coatings and LBE. For the practical application, interface bonding strength is another main issue for the core component in reactor that directly influence the life time of structural material and coatings. Although the buffer layers have been designed to enhance the interface bonding strength, there are no standards for the coatings applied in high-temperature, high-irradiation LBE environment. A recent study proposed a new method improve bonding strength that may advance application of coating technology in generation IV fast reactor. Surface texture prepared by laser technology with nano or micro width grooves is shown in Figure 10f. Its working mechanism is based on the mechanical locking through the grooves by dispersing shear force. Especially, under shear stress impact of high density LBE, the substrate and the coating material are able to maintain their integrity during the operation. Besides, the substrate surface is more active after the laser treatment, resulting a higher bond strength between the coating and grooves [85]. Recently, Wan et al. [49] synthesized TiSiN coatings on $316 \mathrm{~L}$ steel by cathodic arc ion plating, and found that increasing silicon content enhanced LBE corrosion resistance of TiSiN coating. The outstanding corrosion resistance was considered to be related to the amorphous $\mathrm{Si}_{3} \mathrm{~N}_{4}$ forming in the coating, which can effectively prevent $\mathrm{Pb}$ and $\mathrm{Bi}$ from penetrating into the coating and substrate.
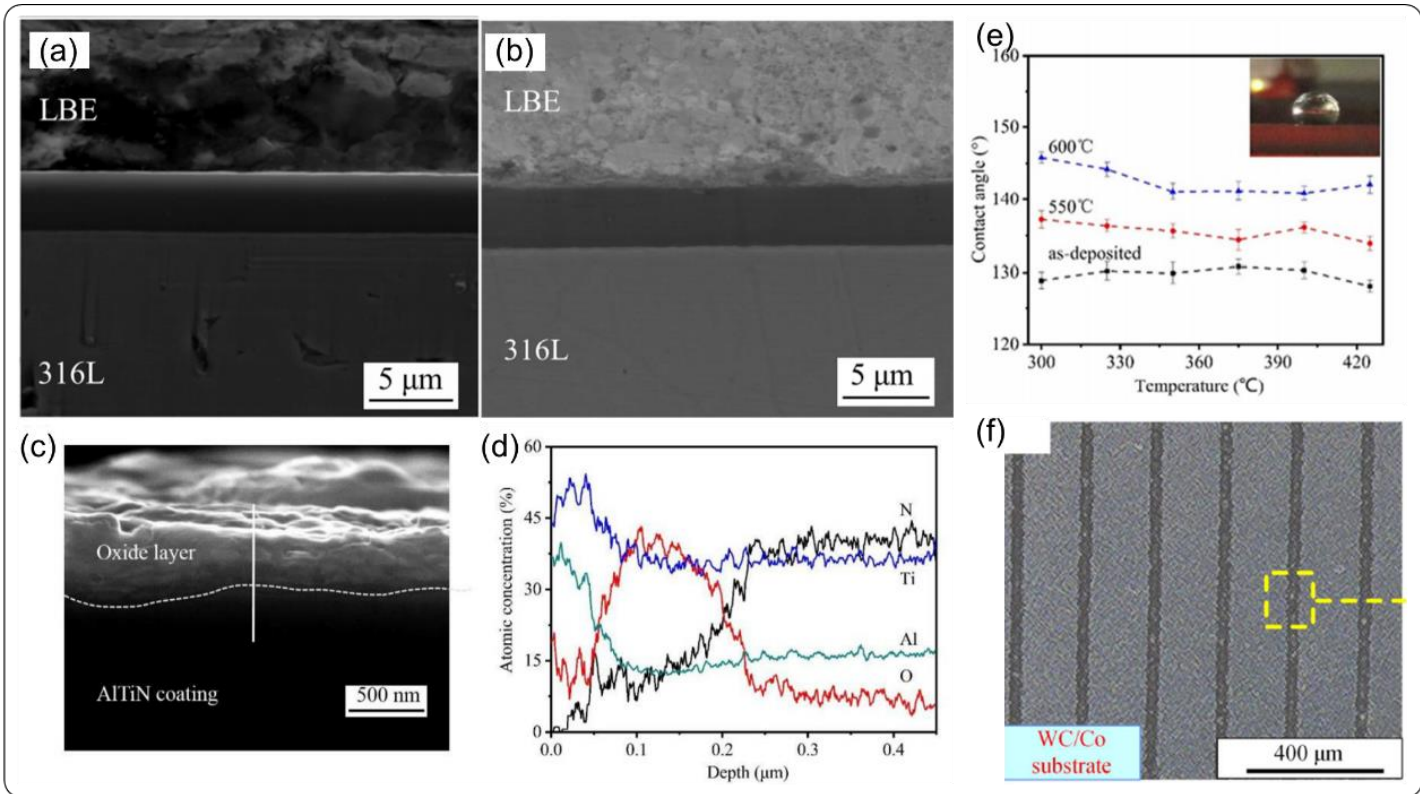

Figure 10. Corrosion performance of TiAlN coating in liquid LBE. (a) morphology of TiAlN coating after $500{ }^{\circ} \mathrm{C}, 500 \mathrm{~h}$ LBE corrosion; (b) topography of TiAlN coating at $600{ }^{\circ} \mathrm{C}$; (c) topography of oxide layer on high-multiplier surface; (d) distribution of oxide layer elements; (e) wetting performance of TiAlN coating and LBE at 290 430 ${ }^{\circ} \mathrm{C}$; (f) microscopic grooves on the surface of a carbide substrate [83,85]. Figure 10a-e is reprinted with permission from Reference [83]. Copyright 2020 Elsevier. Figure 10f is reprinted with permission from Reference [85]. Copyright 2018 Elsevier.

\subsection{Oxide Coatings}

The essential reason that the Al-containing coating discussed above can improve the corrosion resistance of steel in LBE is due to the formation of dense alumina on the surface of steel. Therefore, naturally, some researchers directly prepare aluminum oxide or other dense and highly stable oxide coatings on cladding steels. Therefore, the most effective method for protecting bare steel is to fabricate $\mathrm{Al}_{2} \mathrm{O}_{3}$ coatings on the surface directly. Figure 10 compared the photos and microstructure of the uncoated and $\mathrm{Al}_{2} \mathrm{O}_{3}$ 
coated 1515Ti tubes (prepared by pulsed laser deposition) before and after LBE corrosion (550 ${ }^{\circ} \mathrm{C}$ with an oxygen content of $10^{-8} \mathrm{wt} . \%$ ) [86]. The image of the uncoated 1515Ti tubes before and after the test is shown in Figure 11a,b. without protective coatings, the $\mathrm{Pb}$ element penetrated up to $50 \mu \mathrm{m}$ of substrate. Whereas it can be seen that there is no significant corrosion phenomenon between the liquid metal and the $\mathrm{Al}_{2} \mathrm{O}_{3}$ coatings that prepared by pulsed laser deposition (PLD). In Figure 11f, the diffusion of $\mathrm{Pb}$ and the alloying element are hindered by $\mathrm{Al}_{2} \mathrm{O}_{3}$ coatings effectively. In conclusion, the authors used PLD-grown $\mathrm{Al}_{2} \mathrm{O}_{3}$ coatings to maintain structural integrity and adhesion during irradiation, thermal cycling, cyclic nano-impact, and scratching. This is promising way to ensure corrosion resistance in LFR-related environments. In addition, $\mathrm{Al}_{2} \mathrm{O}_{3}$ coatings with a thickness of $1.5 \mu \mathrm{m}$ was also prepared by radio frequency magnetron sputtering (RFMS) at low temperature $\left(260^{\circ} \mathrm{C}\right)$ and the coating maintained good integrity after $1200 \mathrm{~h}$ of corrosion [81].

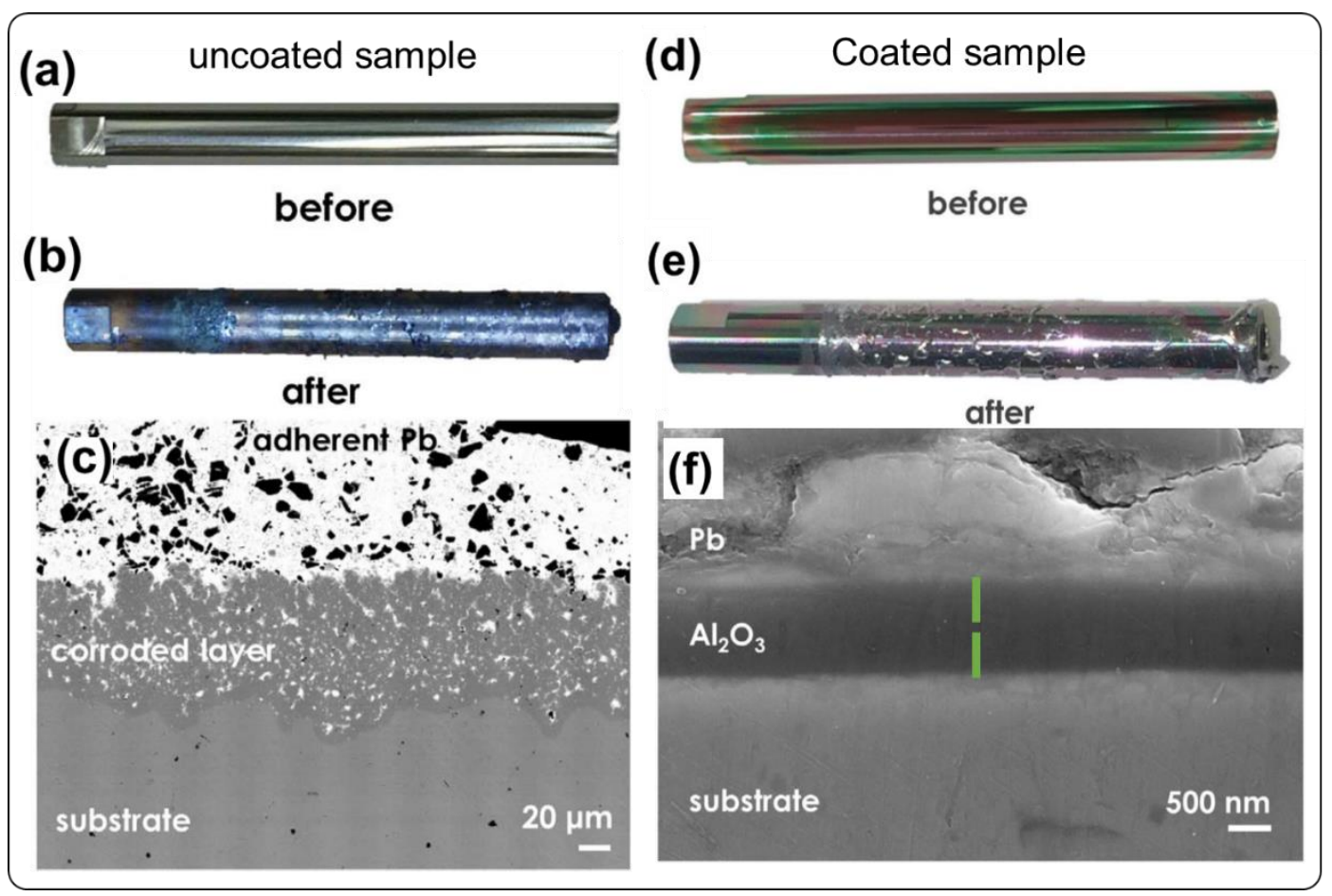

Figure 11. Corrosion resistance evaluation of $\mathrm{Al}_{2} \mathrm{O}_{3}$ coatings on the cladding tubes. (a-c) the surface of cladding tube before after corrosion and its cross-section image. (d-f) The appearance of cladding tube before and after corrosion and its cross-section image [86]. Figure 11 is reprinted with permission from Reference [86]. Copyright 2017 Elsevier.

\subsection{Amorphous and High-Entropy Alloy Coatings}

As mentioned above, for the TiSiN coatings deposited on $316 \mathrm{~L}$ steel by cathodic arc ion plating, it is $\mathrm{Si}_{3} \mathrm{~N}_{4}$ with the amorphous structure that really improves the corrosion resistance of high temperature LBE. Amorphous $\mathrm{SiO}_{2}$ and amorphous $\mathrm{Al}_{2} \mathrm{O}_{3}$ have also been found to have such excellent properties $[36,87,88]$. It should be noted that these amorphous phases are mostly produced in the LBE corrosion process of the crystalline coatings, and so far there are no reports on the corrosion behavior of bulk amorphous coating in the high-temperature LBE. In addition, amorphous materials have excellent corrosion resistance and mechanical properties, but they are in a metastable state and may crystallize in high-temperature LBE after long-term work, resulting in reduced corrosion resistance. However, recently, crystalline and amorphous multiphase ceramic coating was reported to have excellent corrosion resistance properties even at $550{ }^{\circ} \mathrm{C}$ for $300 \mathrm{~h}$ [88]. Nanocrystalline $\mathrm{Al}_{2} \mathrm{O}_{3}$ /amorphous $\mathrm{Al}_{2} \mathrm{O}_{3}$ composite coating was also reported to be able to protect steels operating in heavy liquid metals at high temperature [51]. Therefore, the 
development of the amorphous coatings with a higher crystallization temperature or the crystalline and amorphous composite coatings may become a way to solve this problem.

High-entropy alloy (HEA, and its variants of medium-entropy alloy, MEA) has excellent mechanical properties and corrosion resistance, and have received extensive attention from researchers in recent years. Up to now, there are very few reports on the corrosion behavior and corrosion mechanism of high-entropy alloys and high-entropy alloy coatings in high-temperature LBE. Recently, Gong et al. [89] reported the corrosion behavior of a dual-phase Al0.7CoCrFeNi HEA exposed to oxygen-saturated LBE at 350 and $500{ }^{\circ} \mathrm{C}$, as shown in Figure 12. It is found that the BCC (body-centered cubic) phase rich in (Ni, Al) became brittle in LBE (Figure 12a), specifically, intragrain cracking within this phase occurs at $350{ }^{\circ} \mathrm{C}$ (Figure 12b), while the disjointness cracking of the BCC/FCC (face-centered cubic) phase boundary occurs at $500{ }^{\circ} \mathrm{C}$ (Figure 12c). On the contrary, the brittleness of the $\left(\mathrm{Co}, \mathrm{Cr}, \mathrm{Fe}\right.$ )-rich (FCC) phase was rarely observed at both $350{ }^{\circ} \mathrm{C}$ and $500{ }^{\circ} \mathrm{C}$ (Figure 12a).
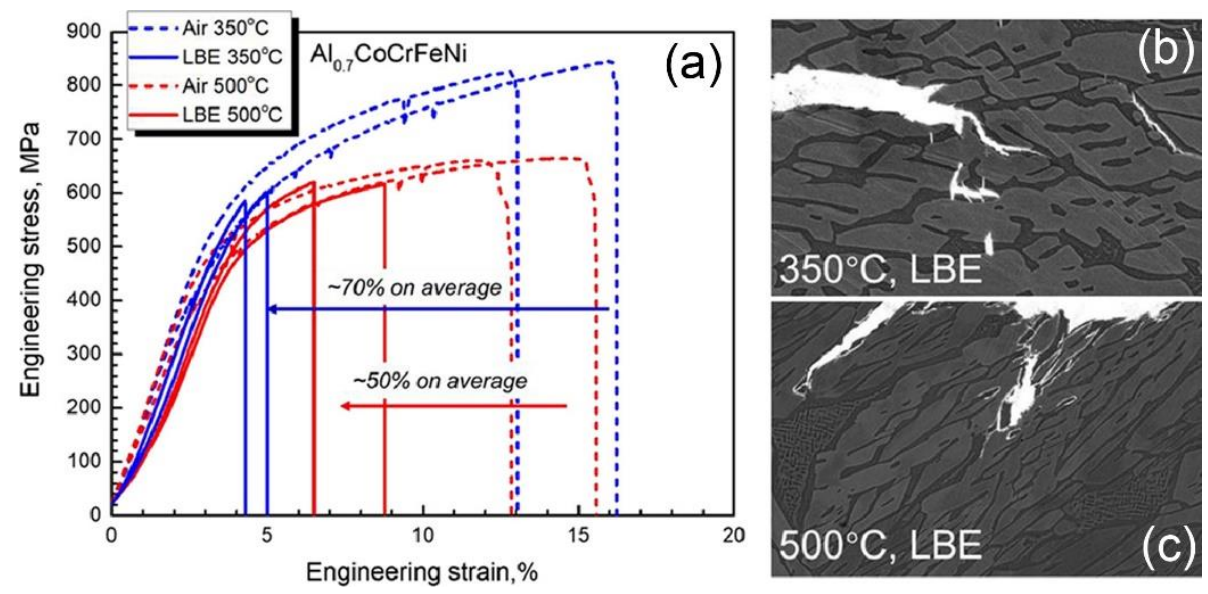

Figure 12. Liquid metal embrittlement of Al0.7CoCrFeNi HEA exposed to oxygen-saturated LBE. (a) Engineering stress-strain curves tested in air and LBE at different temperatures. (b,c) SEM images after LBE corrosion [89]. Figure 12 is reprinted with permission from Reference [89]. Copyright 2021 Elsevier.

The development of HEA and/or MEA (including composition, phase and structure design) against the liquid metal brittleness and the study of their corrosion behavior and corrosion mechanism in high temperature LBE may become the next research hotspot. The HEAs and MEAs coatings can be easily deposited by pulsed laser on steels and other cladding materials [43,90-92], co-evaporating single-element metal and alloy targets [93], or thermal spray process [94]. It is believed that once the liquid metal embrittlement and compatibility is resolved, HEA coatings will soon be applied on the candidate cladding materials.

It should be noted that the impact of the coating process on the substrate should be as small as possible, or even none. However, it is difficult to meet this requirement in the actual process. For example, when using thermal diffusion technology to prepare a metal or alloy coating on the steel surface, in order to increase the diffusion rate of atoms and/or ions, a higher heating temperature is required. However, at high heating temperatures, it is easy to decarburize the surface layer and coarsen the microstructure of the steel substrate $[37,95-97]$. Therefore, it is considered that a temperature lower than the working temperature of the material should be selected as much as possible for coating preparation [98]. However, for thermal diffusion coatings, generally lowering the temperature will seriously slow down the diffusion rate of atoms and/or ions [99], thereby worsening the growth rate of the coating. For the deposited coating (e.g., PVD), although the high temperature is heated on the target, recent research results show that the morphology of the coating and the adhesion between the coating and the substrate directly 
depend on the temperature of the substrate material [100]. Therefore, it is also necessary to study and optimize the coating technology and process.

\section{Summary and Outlooks}

In addition to good neutron radiation resistance, the candidate cladding materials and their coatings used in LBE-LFR need to have the following properties: firstly, good resistance to high-temperature LBE corrosion. Specifically, during the entire life, the corrosion thickness loss should not exceed half the thickness of the materials or coatings, where the life of the reactor components and their coatings is designed to exceed 20 years; secondly, excellent thermal shock resistance. The components in the reactor are usually affected by thermal fluctuations [101], especially inside and near the reactor core, and the cladding material and/or its coating must be able to withstand large temperature gradients when the reactor is shut down suddenly. Additionally, for coatings, thermal shock will cause stress between coatings and substrate, and the difference in thermal expansion coefficient will reduce the coating/substrate bond [88,102].

We aim to improve the performance of the material and optimize the service environment to jointly solve the corrosion problem of the cladding steels working under high-temperature LBE. For the former, the corrosion resistance of materials can be improved through alloy design and optimization (including overall and only on the surface of the materials), such as adding strong oxide former $\mathrm{Al}$ and/or $\mathrm{Si}$ to grow a protective oxide layer. The corrosion resistance of the alloyed or coated cladding steels is closely related to oxygen concentration of the LBE, so it is also necessary to study the oxygen control process and technology.

Author Contributions: Investigation and data curation, H.W. (Hao Wang), X.Y. and Y.C.; formal analysis and resources, J.X. and H.W. (Hui Wang); writing —original draft preparation, H.W. (Hao Wang) and X.Y.; writing - review and editing, N.G.; project administration and funding acquisition, H.W. (Hao Wang), H.W. (Hui Wang) and Y.C. All authors have read and agreed to the published version of the manuscript.

Funding: Research was supported by National Natural Science Foundation of China (Grant Nos. 51971207, 51801194), Doctoral Fund of Ministry of Education of China (Grant No. 2020M673291).

Institutional Review Board Statement: Not applicable.

Informed Consent Statement: Not applicable.

Data Availability Statement: Publicly available datasets were discussed in this study. These data can be found in the listed references below.

Conflicts of Interest: The authors declare no conflict of interest.

\section{References}

1. Neumann, A.; Sorge, L.; von Hirschhausen, C.; Wealer, B. Democratic quality and nuclear power: Reviewing the global determinants for the introduction of nuclear energy in 166 countries. Energy Res. Soc. Sci. 2020, 63, 101389. [CrossRef]

2. Omri, A.; Ben Mabrouk, N.; Sassi-Tmar, A. Modeling the causal linkages between nuclear energy, renewable energy and economic growth in developed and developing countries. Renew. Sustain. Energy Rev. 2015, 42, 1012-1022. [CrossRef]

3. Meng, T.; Cheng, K.; Zeng, C.; He, Y.; Tan, S. Preliminary control strategies of megawatt-class gas-cooled space nuclear reactor with different control rod configurations. Prog. Nucl. Energy 2019, 113, 135-144. [CrossRef]

4. Mu, R.; Zuo, J.; Yuan, X. China's approach to nuclear safety-From the perspective of policy and institutional system. Energy Policy 2015, 76, 161-172. [CrossRef]

5. Lorusso, P.; Bassini, S.; Del Nevo, A.; Di Piazza, I.; Giannetti, F.; Tarantino, M.; Utili, M. GEN-IV LFR development: Status \& perspectives. Prog. Nucl. Energy 2018, 105, 318-331. [CrossRef]

6. Alemberti, A.; Carlsson, J.; Malambu, E.; Orden, A.; Struwe, D.; Agostini, P.; Monti, S. European lead fast reactor-ELSY. Nucl. Eng. Des. 2011, 241, 3470-3480. [CrossRef]

7. Smith, C.F.; Halsey, W.G.; Brown, N.W.; Sienicki, J.J.; Moisseytsev, A.; Wade, D.C. SSTAR: The US lead-cooled fast reactor (LFR). J. Nucl. Mater. 2008, 376, 255-259. [CrossRef]

8. Abram, T.; Ion, S. Generation-IV nuclear power: A review of the state of the science. Energy Policy 2008, 36, 4323-4330. [CrossRef] 
9. Obara, T.; Miura, T.; Sekimoto, H. Fundamental study of polonium contamination by neutron irradiated lead-bismuth eutectic. J. Nucl. Mater. 2005, 343, 297-301. [CrossRef]

10. Forgione, N.; Castelliti, D.; Gerschenfeld, A.; Polidori, M.; Del Nevo, A.; Hu, R. Thermal Hydraulics Aspects of Liquid Metal Cooled Nuclear Reactors; Elsevier: Amsterdam, The Netherlands, 2019; pp. 157-184.

11. Alemberti, A.; Tuček, K.; Obara, T.; Moiseev, A.; Tocheny, L.; Hwang, I.; Smith, C.; Wu, Y.; Zhou, T. Status of Generation-IV Lead Fast Reactor Activities. 2017. Available online: https://inis.iaea.org/search/search.aspx?orig_q=RN:51002820 (accessed on 22 October 2020).

12. Zhang, J. A review of steel corrosion by liquid lead and lead-bismuth. Corros. Sci. 2009, 51, 1207-1227. [CrossRef]

13. Gong, X.; Chen, J.; Hu, F.; Xiang, C.; Yu, Z.; Xiao, J.; Wang, H.; Gong, H.; Wang, H.; Liu, C.; et al. Liquid metal embrittlement of an Fe10Cr4Al ferritic alloy exposed to oxygen-depleted and -saturated lead-bismuth eutectic at $350{ }^{\circ} \mathrm{C}$. Corros. Sci. 2020, 165, 108364. [CrossRef]

14. Park, J.J.; Butt, D.P.; Beard, C.A. Review of liquid metal corrosion issues for potential containment materials for liquid lead and lead-bismuth eutectic spallation targets as a neutron source. Nucl. Eng. Des. 2000, 196, 315-325. [CrossRef]

15. Ballinger, R.G.; Lim, J. An Overview of Corrosion Issues for the Design and Operation of High-Temperature Lead- and LeadBismuth-Cooled Reactor Systems. Nucl. Technol. 2004, 147, 418-435. [CrossRef]

16. Lambrinou, K.; Charalampopoulou, E.; Van der Donck, T.; Delville, R.; Schryvers, D. Dissolution corrosion of 316L austenitic stainless steels in contact with static liquid lead-bismuth eutectic (LBE) at $500{ }^{\circ} \mathrm{C}$. J. Nucl. Mater. 2017, 490, 9-27. [CrossRef]

17. Serre, I.P.; Vogt, J.-B. Liquid metal embrittlement sensitivity of the T91 steel in lead, in bismuth and in lead-bismuth eutectic. J. Nucl. Mater. 2020, 531, 152021. [CrossRef]

18. Tunca, B.; Lapauw, T.; Callaert, C.; Hadermann, J.; Delville, R.; Caspi, E.N.; Dahlqvist, M.; Rosén, J.; Marshal, A.; Pradeep, K.G.; et al. Compatibility of Zr2AlC MAX phase-based ceramics with oxygen-poor, static liquid lead-bismuth eutectic. Corros. Sci. 2020, 171, 108704. [CrossRef]

19. Wu, Y. Design and R\&D Progress of China Lead-Based Reactor for ADS Research Facility. Engineering 2016, 2, 124-131. [CrossRef]

20. Gong, X.; Li, R.; Sun, M.; Ren, Q.; Liu, T.; Short, M.P. Opportunities for the LWR ATF materials development program to contribute to the LBE-cooled ADS materials qualification program. J. Nucl. Mater. 2016, 482, 218-228. [CrossRef]

21. Konings, R.; Stoller, R. Comprehensive Nuclear Materials; Elsevier: Amsterdam, The Netherlands, 2012; pp. $207-219$.

22. Pascal, Y. Structural Materials for Generation IV Nuclear Reactors; Elsevier: Amsterdam, The Netherlands, 2017 ; pp. 569-594.

23. Xu, S.; Zhou, Z.; Long, F.; Jia, H.; Guo, N.; Yao, Z.; Daymond, M.R. Combination of back stress strengthening and Orowan strengthening in bimodal structured Fe-9Cr-Al ODS steel with high Al addition. Mater. Sci. Eng. A 2019, 739, 45-52. [CrossRef]

24. Xu, S.; Zhou, Z.; Long, F.; Jia, H.; Guo, N.; Sun, Y.; Yao, Z.; Daymond, M.R. Influence of al addition strategy on the microstructure of a low-cr oxide dispersion-strengthened (ODS) Ferritic Steel. Adv. Eng. Mater. 2020, 22, 1900879. [CrossRef]

25. Wang, C.; Luo, J.; Guo, N.; Tu, J.; Ye, H.; Zhang, P.; Yan, Q. Effect of Yttrium Contents on the Microstructure of a Hot-Rolled Tantalum-Containing 12Cr-ODS Steel. Front. Mater. 2019, 6, 6. [CrossRef]

26. Klueh, R.; Nelson, A. Ferritic/martensitic steels for next-generation reactors. J. Nucl. Mater. 2007, 371, 37-52. [CrossRef]

27. Prasitthipayong, A.; Frazer, D.; Kareer, A.; Abad, M.D.; Garner, A.; Joni, B.; Ungar, T.; Ribarik, G.; Preuss, M.; Balogh, L.; et al. Micro mechanical testing of candidate structural alloys for Gen-IV nuclear reactors. Nucl. Mater. Energy 2018, 16, 34-45. [CrossRef]

28. Murty, K.L.; Charit, I. Structural materials for Gen-IV nuclear reactors: Challenges and opportunities. J. Nucl. Mater. 2008, 383, 189-195. [CrossRef]

29. Lapauw, T.; Tunca, B.; Joris, J.; Jianu, A.; Fetzer, R.; Weisenburger, A.; Vleugels, J.; Lambrinou, K. Interaction of $\mathrm{M}_{\mathrm{n}+1} \mathrm{AX}_{\mathrm{n}}$ phases with oxygen-poor, static and fast-flowing liquid lead-bismuth eutectic. J. Nucl. Mater. 2019, 520, 258-272. [CrossRef]

30. Schroer, C.; Wedemeyer, O.; Skrypnik, A.; Novotny, J.; Konys, J. Corrosion kinetics of Steel T91 in flowing oxygen-containing lead-bismuth eutectic at $450{ }^{\circ} \mathrm{C}$. J. Nucl. Mater. 2012, 431, 105-112. [CrossRef]

31. Hosemann, P.; Hawley, M.; Koury, D.; Welch, J.; Johnson, A.; Mori, G.; Li, N.; Maloy, S. Nanoscale characterization of HT-9 exposed to lead bismuth eutectic at $550{ }^{\circ} \mathrm{C}$ for 3000 h. J. Nucl. Mater. 2008, 381, 211-215. [CrossRef]

32. Schroer, C.; Koch, V.; Wedemeyer, O.; Skrypnik, A.; Konys, J. Silicon-containing ferritic/martensitic steel after exposure to oxygen-containing flowing lead-bismuth eutectic at 450 and $550{ }^{\circ} \mathrm{C}$. J. Nucl. Mater. 2016, 469, 162-176. [CrossRef]

33. Barbier, F.; Rusanov, A. Corrosion behavior of steels in flowing lead-bismuth. J. Nucl. Mater. 2001, 296, 231-236. [CrossRef]

34. Tan, L.; Yang, Y.; Allen, T. Oxidation behavior of iron-based alloy HCM12A exposed in supercritical water. Corros. Sci. 2006, 48, 3123-3138. [CrossRef]

35. Allen, T.R.; Sridharan, K.; Machut, M.T.; Tan, L. Surface Treatment to Improve Corrosion Resistance in Lead-Alloy Coolants; University of Wisconsin: Madison, WI, USA, 2007.

36. Vogt, J.-B.; Serre, I.P. A Review of the Surface Modifications for Corrosion Mitigation of Steels in Lead and LBE. Coatings 2021, 11, 53. [CrossRef]

37. Zeng, J.; Hu, J.; Yang, X.; Xu, H.; Li, H.; Guo, N. Evolution of the Microstructure and Properties of Pre-Boronized Coatings During Pack-Cementation Chromizing. Coatings 2020, 10, 159. [CrossRef]

38. Lin, N.; Zhao, L.; Liu, Q.; Zou, J.; Xie, R.; Yuan, S.; Li, D.; Zhang, L.; Wang, Z.; Tang, B. Preparation of titanizing coating on AISI 316 stainless steel by pack cementation to mitigate surface damage: Estimations of corrosion resistance and tribological behavior. J. Phys. Chem. Solids 2019, 129, 387-400. [CrossRef] 
39. Zeng, J.; Hu, J.; Yang, X.; Xu, H.; Li, H.; Guo, N.; Dong, Q. Microstructure and formation mechanism of the Si-Cr dual-alloyed coating prepared by pack-cementation. Surf. Coat. Technol. 2020, 399, 126142. [CrossRef]

40. Umretiya, R.V.; Elward, B.; Lee, D.; Anderson, M.; Rebak, R.B.; Rojas, J.V. Mechanical and chemical properties of PVD and cold spray Cr-coatings on Zircaloy-4. J. Nucl. Mater. 2020, 541, 152420. [CrossRef]

41. Mouche, P.; Ang, C.; Koyanagi, T.; Doyle, P.; Katoh, Y. Characterization of PVD Cr, CrN, and TiN coatings on SiC. J. Nucl. Mater. 2019, 527, 151781. [CrossRef]

42. Endrino, J.L.; Fox-Rabinovich, G.S.; Gey, C. Hard AlTiN, AlCrN PVD coatings for machining of austenitic stainless steel. Surf. Coat. Technol. 2006, 200, 6840-6845. [CrossRef]

43. Xiang, K.; Chen, L.-Y.; Chai, L.; Guo, N.; Wang, H. Microstructural characteristics and properties of CoCrFeNiNbx high-entropy alloy coatings on pure titanium substrate by pulsed laser cladding. Appl. Surf. Sci. 2020, 517, 146214. [CrossRef]

44. Chai, L.; Wu, H.; Zheng, Z.; Guan, H.; Pan, H.; Guo, N.; Song, B. Microstructural characterization and hardness variation of pure Ti surface-treated by pulsed laser. J. Alloys Compd. 2018, 741, 116-122. [CrossRef]

45. Chai, L.; Chen, K.; Zhi, Y.; Murty, K.L.; Chen, L.-Y.; Yang, Z. Nanotwins induced by pulsed laser and their hardening effect in a Zr alloy. J. Alloys Compd. 2018, 748, 163-170. [CrossRef]

46. Liu, F.; Shan, D.; Song, Y.; Han, E.-H.; Ke, W. Corrosion behavior of the composite ceramic coating containing zirconium oxides on AM30 magnesium alloy by plasma electrolytic oxidation. Corros. Sci. 2011, 53, 3845-3852. [CrossRef]

47. Malinovschi, V.; Marin, A.; Negrea, D.; Andrei, V.; Coaca, E.; Mihailescu, C.; Lungu, C.P. Characterization of $\mathrm{Al}_{2} \mathrm{O}_{3} / \mathrm{ZrO}_{2}$ composite coatings deposited on $\mathrm{Zr}-2.5 \mathrm{Nb}$ alloy by plasma electrolytic oxidation. Appl. Surf. Sci. 2018, 451, 169-179. [CrossRef]

48. Wang, Y.; Jiang, Z.; Yao, Z.; Tang, H. Microstructure and corrosion resistance of ceramic coating on carbon steel prepared by plasma electrolytic oxidation. Surf. Coat. Technol. 2010, 204, 1685-1688. [CrossRef]

49. Wan, Q.; Wu, Z.; Liu, Y.; Yang, B.; Liu, H.; Ren, F.; Wang, P.; Xiao, Y.; Zhang, J.; Zhang, G. Lead-bismuth eutectic (LBE) corrosion mechanism of nano-amorphous composite TiSiN coatings synthesized by cathodic arc ion plating. Corros. Sci. 2021, 183, 109264. [CrossRef]

50. Sanchette, F.; Ducros, C.; Schmitt, T.; Steyer, P.; Billard, A. Nanostructured hard coatings deposited by cathodic arc deposition: From concepts to applications. Surf. Coatings Technol. 2011, 205, 5444-5453. [CrossRef]

51. Ferré, F.G.; Ormellese, M.; Di Fonzo, F.; Beghi, M. Advanced $\mathrm{Al}_{2} \mathrm{O}_{3}$ coatings for high temperature operation of steels in heavy liquid metals: A preliminary study. Corros. Sci. 2013, 77, 375-378. [CrossRef]

52. Xu, S.; Long, F.; Persaud, S.Y.; Guo, N.; Yao, Z.; Daymond, M.R.; Gao, W.; Zhang, L.; Zhou, Z. Oxidation behavior of 9Cr-4.5Al ODS steel in $600{ }^{\circ} \mathrm{C}$ supercritical water and the effect of pre-oxidation. Corros. Sci. 2020, 165, 108380. [CrossRef]

53. Zhang, G.; Zhou, Z.; Mo, K.; Wang, P.; Miao, Y.; Li, S.; Wang, M.; Liu, X.; Gong, M.; Almer, J.; et al. The microstructure and mechanical properties of Al-containing 9Cr ODS ferritic alloy. J. Alloys Compd. 2015, 648, 223-228. [CrossRef]

54. Xiang, Z.D.; Burnell-Gray, J.S.; Datta, P.K. Aluminide coating formation on nickel-base superalloys by pack cementation process. J. Mater. Sci. 2001, 36, 5673-5682. [CrossRef]

55. Kurata, Y.; Futakawa, M.; Saito, S. Corrosion behavior of Al-surface-treated steels in liquid Pb-Bi in a pot. J. Nucl. Mater. 2004, 335, 501-507. [CrossRef]

56. Abdolahi, B.; Shahverdi, H.; Torkamany, M.; Emami, M. Improvement of the corrosion behavior of low carbon steel by laser surface alloying. Appl. Surf. Sci. 2011, 257, 9921-9924. [CrossRef]

57. Engelko, V.; Mueller, G.; Rusanov, A.; Markov, V.; Tkachenko, K.; Weisenburger, A.; Kashtanov, A.; Chikiryaka, A.; Jianu, A. Surface modification/alloying using intense pulsed electron beam as a tool for improving the corrosion resistance of steels exposed to heavy liquid metals. J. Nucl. Mater. 2011, 415, 270-275. [CrossRef]

58. Xu, J.; Liu, F.; Wang, F.; Yu, D.; Zhao, L. The corrosion resistance behavior of $\mathrm{Al}_{2} \mathrm{O}_{3}$ coating prepared on NiTi alloy by micro-arc oxidation. J. Alloys Compd. 2009, 472, 276-280. [CrossRef]

59. Popovic, M.; Bolind, A.; Aussat, Y.; Gubser, A.; Hosemann, P. Oxidative passivation of Fe-Cr-Al steels in lead-bismuth eutectic under oxygen-controlled static conditions at $700^{\circ}$ and $800^{\circ} \mathrm{C}$. J. Nucl. Mater. 2019, 523, 172-181. [CrossRef]

60. Qiu, J.; Han, J.; Schoell, R.; Popovic, M.; Ghanbari, E.; Kaoumi, D.; Scully, J.R.; Macdonald, D.D.; Hosemann, P. Electrical properties of thermal oxide scales on pure iron in liquid lead-bismuth eutectic. Corros. Sci. 2020, 176, 109052. [CrossRef]

61. Liu, W.; Wang, Y.; Ge, H.; Li, L.; Ding, Y.; Meng, L.; Zhang, X. Microstructure evolution and corrosion behavior of Fe-Al-based intermetallic aluminide coatings under acidic condition. Trans. Nonferr. Metal Soc. 2018, 28, 2028-2043. [CrossRef]

62. Liu, X.; Yang, D.; Yang, Y.; Chai, X.; Xiong, J.; Zhang, T.; Cheng, X. Computational fluid dynamics and subchannel analysis of lead-bismuth eutectic-cooled fuel assembly under various blockage conditions. Appl. Therm. Eng. 2020, 164, 114419. [CrossRef]

63. Engelko, V.; Yatsenko, B.; Mueller, G.; Bluhm, H. Pulsed electron beam facility (GESA) for surface treatment of materials. Vacuum 2001, 62, 211-216. [CrossRef]

64. Proskurovsky, D.; Rotshtein, V.; Ozur, G.; Markov, A.; Nazarov, D.; Shulov, V.; Ivanov, Y.F.; Buchheit, R. Pulsed electron-beam technology for surface modification of metallic materials. J. Vac. Sci. Technol. A 1998, 16, 2480-2488. [CrossRef]

65. Heinzel, A.; Kondo, M.; Takahashi, M. Corrosion of steels with surface treatment and Al-alloying by GESA exposed in leadbismuth. J. Nucl. Mater. 2006, 350, 264-270. [CrossRef]

66. Glasbrenner, H.; Konys, J.; Mueller, G.; Rusanov, A. Corrosion investigations of steels in flowing lead at $400{ }^{\circ} \mathrm{C}$ and $550{ }^{\circ} \mathrm{C}$. J. Nucl. Mater. 2001, 296, 237-242. [CrossRef] 
67. Cionea, C.; Abad, M.; Aussat, Y.; Frazer, D.; Gubser, A.; Hosemann, P. Oxide scale formation on 316L and FeCrAl steels exposed to oxygen controlled static LBE at temperatures up to $800^{\circ} \mathrm{C}$. Sol. Energy Mater. Sol. Cells 2016, 144, 235-246. [CrossRef]

68. Fetzer, R.; Weisenburger, A.; Jianu, A.; Müller, G. Oxide scale formation of modified FeCrAl coatings exposed to liquid lead. Corros. Sci. 2012, 55, 213-218. [CrossRef]

69. Weisenburger, A.; Heinzel, A.; Müller, G.; Muscher, H.; Rousanov, A. T91 cladding tubes with and without modified FeCrAlY coatings exposed in LBE at different flow, stress and temperature conditions. J. Nucl. Mater. 2008, 376, 274-281. [CrossRef]

70. Laidler, K.J. The development of the Arrhenius equation. J. Chem. Educ. 1984, 61, 494. [CrossRef]

71. Chen, Y.; Qiu, C.; Hu, L.; Nong, Y.; Liu, Z.; He, B. The Corrosion Behavior of Multiphase Ceramic Protective Coatings on China Low Activation Martensitic Steel Surface in Flowing Liquid Lead-Bismuth Eutectic. Steel Res. Int. 2017, 88, 1600413. [CrossRef]

72. Short, M.P.; Ballinger, R.G.; Hänninen, H.E. Corrosion resistance of alloys F91 and Fe-12Cr-2Si in lead-bismuth eutectic up to 715 ${ }^{\circ}$ C. J. Nucl. Mater. 2013, 434, 259-281. [CrossRef]

73. Gong, X.; Yang, Z.; Deng, Y.; Xiao, J.; Wang, H.; Yu, Z.; Yin, Y. Creep failure of a solution-annealed 15-15Ti steel exposed to stagnant lead-bismuth eutectic at 550 and $600^{\circ} \mathrm{C}$. Mater. Sci. Eng. A 2020, 798, 140230. [CrossRef]

74. Rivai, A.K.; Takahashi, M. Compatibility of surface-coated steels, refractory metals and ceramics to high temperature lead-bismuth eutectic. Prog. Nucl. Energy 2008, 50, 560-566. [CrossRef]

75. Cheng, P.; Chou, P.; Kim, Y.-J. Development of Mo-Based Accident Tolerant LWR Fuel Cladding. IAEA TECDOC Series 2016, 66. Available online: https://inis.iaea.org/search/search.aspx?orig_q=RN:47080122 (accessed on 22 October 2020).

76. Cairang, W.; Ma, S.; Gong, X.; Zeng, Y.; Yang, H.; Xue, D.; Qin, Y.; Ding, X.; Sun, J. Oxidation mechanism of refractory Molybdenum exposed to oxygen-saturated lead-bismuth eutectic at $600^{\circ}$ C. Corros. Sci. 2021, 179, 109132. [CrossRef]

77. Barshilia, H.C.; Prakash, M.S.; Jain, A.; Rajam, K. Structure, hardness and thermal stability of TiAlN and nanolayered TiAlN/CrN multilayer films. Vacuum 2005, 77, 169-179. [CrossRef]

78. Jindal, P.; Santhanam, A.; Schleinkofer, U.; Shuster, A. Performance of PVD TiN, TiCN, and TiAlN coated cemented carbide tools in turning. Int. J. Refract. Met. Hard Mater. 1999, 17, 163-170. [CrossRef]

79. Zhou, Z.; Rainforth, W.; Luo, Q.; Hovsepian, P.; Ojeda, J.; Romero-Gonzalez, M. Wear and friction of TiAlN/VN coatings against $\mathrm{Al} 2 \mathrm{O} 3$ in air at room and elevated temperatures. Acta Mater. 2010, 58, 2912-2925. [CrossRef]

80. PalDey, S.; Deevi, S. Single layer and multilayer wear resistant coatings of (Ti,Al)N: A review. Mater. Sci. Eng. A 2003, 342, 58-79. [CrossRef]

81. Miorin, E.; Montagner, F.; Zin, V.; Giuranno, D.; Ricci, E.; Pedroni, M.; Spampinato, V.; Vassallo, E.; Deambrosis, S.M. Al rich PVD protective coatings: A promising approach to prevent T91 steel corrosion in stagnant liquid lead. Surf. Coat. Technol. 2019, 377, 124890. [CrossRef]

82. Anders, A. Tutorial: Reactive high power impulse magnetron sputtering (R-HiPIMS). J. Appl. Phys. 2017, 121, 171101. [CrossRef]

83. Wu, Z.; Zhao, X.; Liu, Y.; Cai, Y.; Li, J.; Chen, H.; Wan, Q.; Yang, D.; Tan, J.; Liu, H.; et al. Lead-bismuth eutectic (LBE) corrosion behavior of AlTiN coatings at 550 and $600{ }^{\circ} \mathrm{C}$. J. Nucl. Mater. 2020, 539, 152280. [CrossRef]

84. Du, X.; Niu, F.; Zhu, H.; Ma, T.; Zhao, Y.; Xiong, W.; Zhang, H. Influence of oxide scale on the wettability of LBE on T91 steel. Fusion Eng. Des. 2017, 125, 378-383. [CrossRef]

85. Zhang, K.; Deng, J.; Guo, X.; Sun, L.; Lei, S. Study on the adhesion and tribological behavior of PVD TiAlN coatings with a multi-scale textured substrate surface. Int. J. Refract. Met. Hard Mater. 2018, 72, 292-305. [CrossRef]

86. Ferré, F.G.; Mairov, A.; Iadicicco, D.; Vanazzi, M.; Bassini, S.; Utili, M.; Tarantino, M.; Bragaglia, M.; Lamastra, F.; Nanni, F.; et al. Corrosion and radiation resistant nanoceramic coatings for lead fast reactors. Corros. Sci. 2017, 124, 80-92. [CrossRef]

87. Johnson, A.L.; Loewen, E.P.; Ho, T.T.; Koury, D.; Hosterman, B.; Younas, U.; Welch, J.; Farley, J.W. Spectroscopic and microscopic study of the corrosion of iron-silicon steel by lead-bismuth eutectic (LBE) at elevated temperatures. J. Nucl. Mater. 2006, 350, 221-231. [CrossRef]

88. Chen, Y.; Hu, L.; Qiu, C.; He, B.; Zhou, L.; Zhao, J.; Li, Y. Influence of LBE Temperatures on the Microstructure and Properties of Crystalline and Amorphous Multiphase Ceramic Coatings. Coatings 2019, 9, 543. [CrossRef]

89. Gong, X.; Xiang, C.; Auger, T.; Chen, J.; Liang, X.; Yu, Z.; Short, M.P.; Song, M.; Yin, Y. Liquid metal embrittlement of a dual-phase Al0.7CoCrFeNi high-entropy alloy exposed to oxygen-saturated lead-bismuth eutectic. Scr. Mater. 2021, 194, 113652. [CrossRef]

90. Xiang, K.; Chai, L.; Wang, Y.; Wang, H.; Guo, N.; Ma, Y.; Murty, K.L. Microstructural characteristics and hardness of CoNiTi medium-entropy alloy coating on pure Ti substrate prepared by pulsed laser cladding. J. Alloys Compd. 2020, 849, 156704. [CrossRef]

91. Wang, L.; Gao, Z.; Wu, M.; Weng, F.; Liu, T.; Zhan, X. Influence of Specific Energy on Microstructure and Properties of Laser Cladded FeCoCrNi High Entropy Alloy. Metals 2020, 10, 1464. [CrossRef]

92. Li, Y.; Liang, H.; Nie, Q.; Qi, Z.; Deng, D.; Jiang, H.; Cao, Z. Microstructures and Wear Resistance of CoCrFeNi2V0.5Tix High-Entropy Alloy Coatings Prepared by Laser Cladding. Crystals 2020, 10, 352. [CrossRef]

93. Chang, Y.-Y.; Chung, C.-H. Tribological and mechanical properties of multicomponent $\mathrm{CrVTiNbZr}(\mathrm{N})$ coatings. Coatings 2021, 11, 41. [CrossRef]

94. Löbel, M.; Lindner, T.; Hunger, R.; Berger, R.; Lampke, T. Precipitation Hardening of the HVOF Sprayed Single-Phase HighEntropy Alloy CrFeCoNi. Coatings 2020, 10, 701. [CrossRef]

95. Hu, J.; Zhang, Y.; Yang, X.; Li, H.; Xu, H.; Ma, C.; Dong, Q.; Guo, N.; Yao, Z. Effect of pack-chromizing temperature on microstructure and performance of AISI 5140 steel with Cr-coatings. Surf. Coat. Technol. 2018, 344, 656-663. [CrossRef] 
96. Hu, J.; Jiang, J.; Li, H.; Yang, X.; Xu, H.; Jin, Y.; Ma, C.; Dong, Q.; Guo, N. Effect of Annealing Treatment on Microstructure and Properties of Cr-Coatings Deposited on AISI 5140 Steel by Brush-Plating. Coatings 2018, 8, 193. [CrossRef]

97. Hu, J.; Pei, Y.; Liu, Y.; Yang, X.; Li, H.; Xu, H.; Guo, N. Microstructure and Properties of Cr-Fe2B Composite Coatings Prepared by Pack-Preboronizing Combined with Electro Brush-Plating. Coatings 2020, 10, 519. [CrossRef]

98. Chaus, A.S.; Pokorný, P.; Čaplovič, L'.; Sitkevich, M.V.; Peterka, J. Complex fine-scale diffusion coating formed at low temperature on high-speed steel substrate. Appl. Surf. Sci. 2018, 437, 257-270. [CrossRef]

99. Wang, Z.; Lu, J.; Lu, K. Chromizing behaviors of a low carbon steel processed by means of surface mechanical attrition treatment. Acta Mater. 2005, 53, 2081-2089. [CrossRef]

100. Bobzin, K.; Brögelmann, T.; Kruppe, N. Enhanced PVD process control by online substrate temperature measurement. Surf. Coatings Technol. 2018, 354, 383-389. [CrossRef]

101. Tauveron, N. Thermal fluctuations in the lower plenum of a high temperature reactor. Nucl. Eng. Des. 2003, 222, 125-137. [CrossRef]

102. Shi, Q.-Q.; Yan, W.; Sha, W.; Wang, W.; Shan, Y.-Y.; Yang, K. Corrosion resistance of self-growing TiC coating on SIMP steel in LBE at $600{ }^{\circ}$ C. Mater. Corros. 2016, 67, 1204-1212. [CrossRef] 